\title{
درجة امتلاك معلمي اللغة العربية في المرحلة الأساسية العليا في مديرية تربية البادية الشمالية الغربية لمهارات التذوق الأدببي

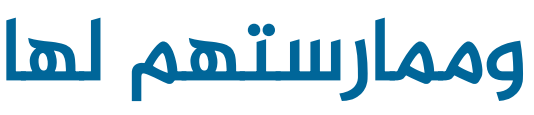

\author{
اديب ذياب حمادنة \\ أستاذ في مناهج اللغة العربية وأساليب تدريسها \\ كلية العلوم التربوية- جامعة آل البيت- الأردن \\ adeebhamadnah@yahoo.com
}




\section{درجـة امتلاك معلمي اللغة العربية في المرحلة الأسـاسية العليا في مديرية تربية البادية الشمالية

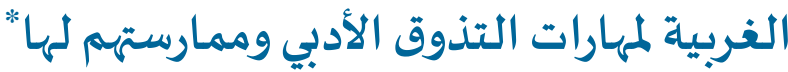

\author{
اديب ذياب حمادنة \\ أستاذ في مناهج اللغة العربية وأساليب تدريسها- كلية العلوم التربوية- جامعة آل البيت- الأردن
} \\ adeebhamadnah@yahoo.com}

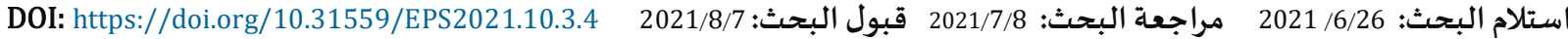

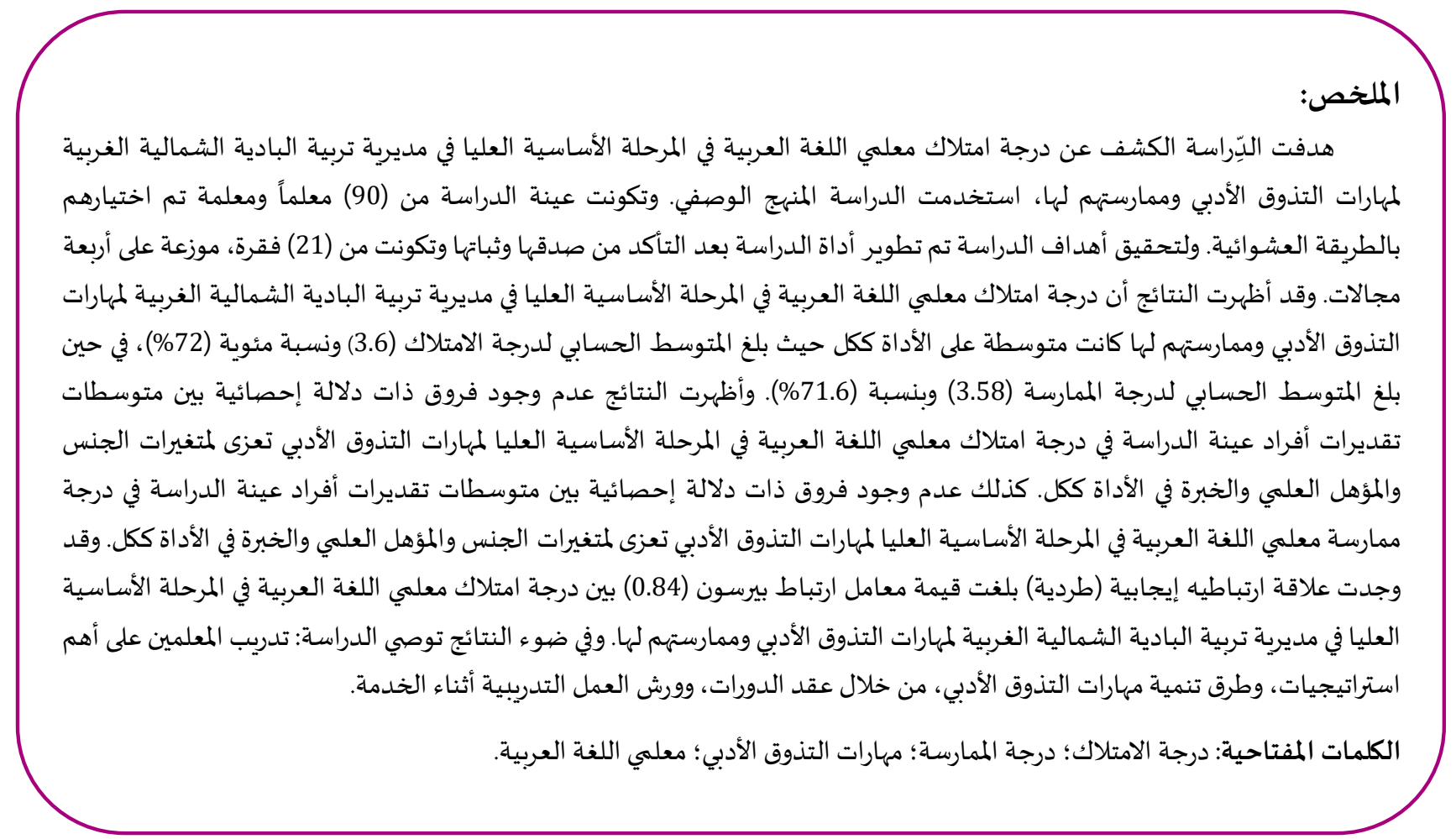

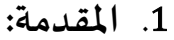

تُعد اللغة العربية من اللغات الحية المشهورة، إنها لغة القرآن الكريم، والحديث النبوي الشريف، هي لغة العرب جميعاً، حيث اطلقوا علهيها

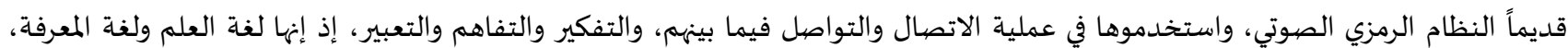

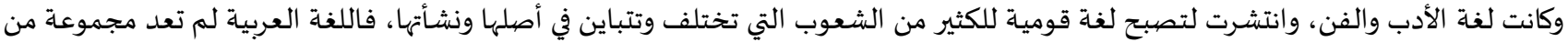

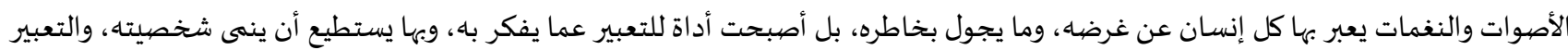

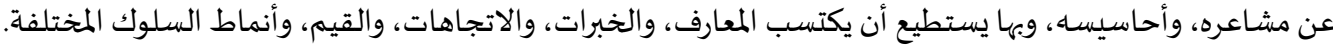

" أجريت هذه الدراسة بدعم من جامعة آل البيت خلال إجازة التفرغ العلمي الممنوحة للباحث خلال العام الدراسي 2021/2020 في الجامعة الأردنية 
ويُعد الأدب أحد الفروع المهمة من فروع اللغة العربية، وتتضح أهمية دراسة الأدب في أنه فن جميل يبعث في النفس السرور والارتياح؛ لما تحتوياه

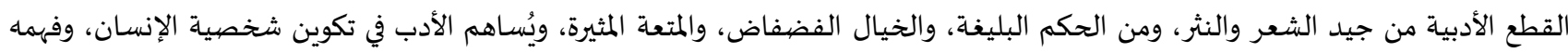

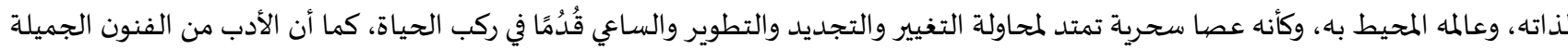

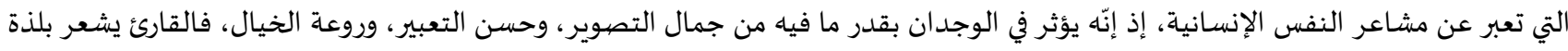

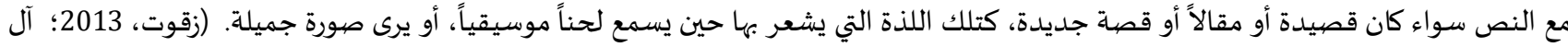

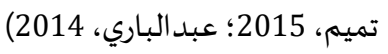
وللأدب دور كبير في تنمية التذوق الأدبي لدى الطلبة بمراحل التعليم العام، في دراكهم لنواحي الجمال، ولهذا فإن تذوق النص الأدبي وتقديره، هو الحصيلة أو الهدف الأسمى من تدريس مادة الأدب، فضلاً عن أنه الحصيلة الهائية لدراسة البلاغة والنقد، وثمرة من ثمرات التعرف على النه أساليبها

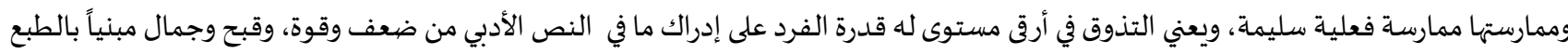

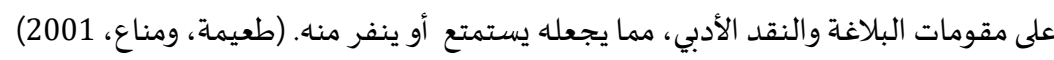

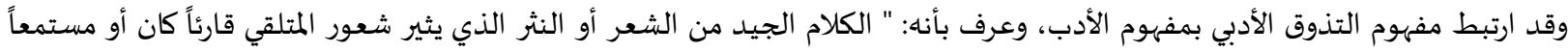

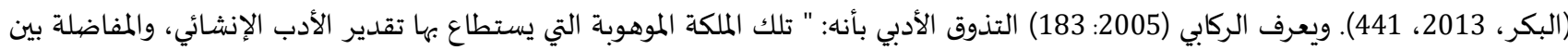
شواهده ونصوصاه، أو تلك الحاسة الفنية التي يهتدي بها في تقويم العمل الأدبي، وعرض مزاياه وعيوبه"، بينما يعرف حبوش ومقابلة (2017: 145)

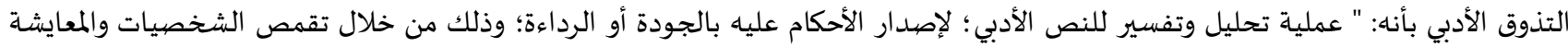

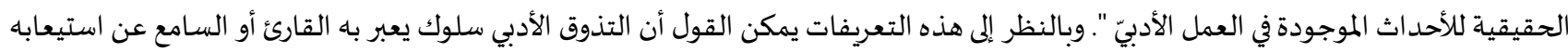

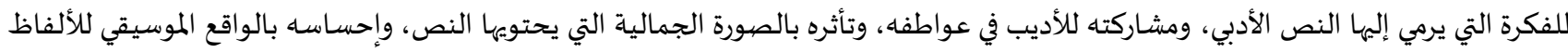

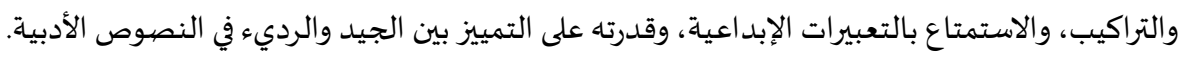

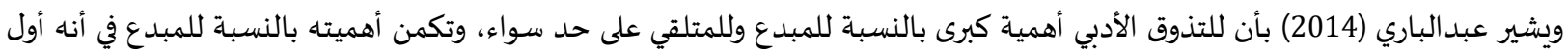

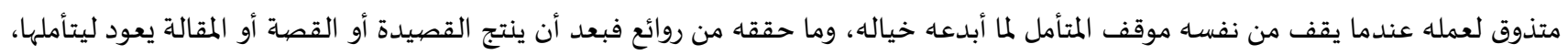

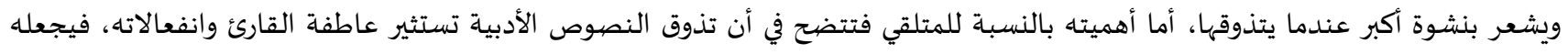

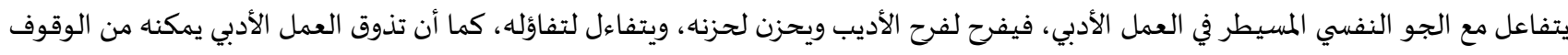

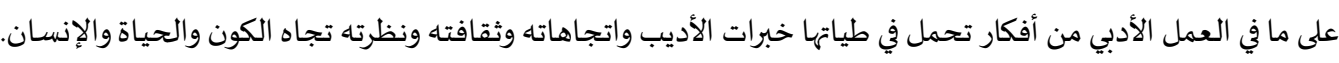

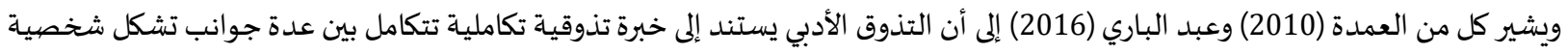
المتلقي، بهدف تحليل النص والنظر فيه من الجوانب الآتية:

الجانب العقلي: يقصد به قدرة المتلقي على فهم واستيعاب النص الأدبي من الناحية الفكرية، وذلك باستخراج الأفكار الواردة فيه، وفههم دلالات

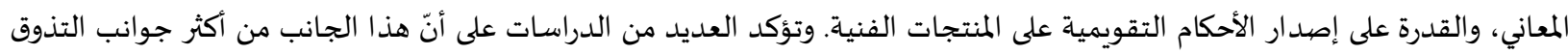

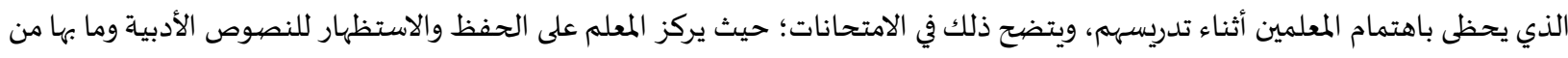

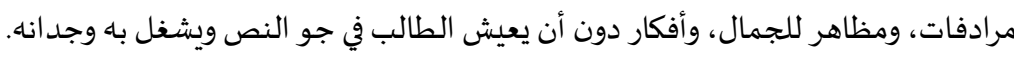

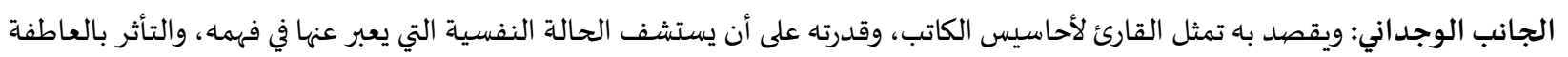

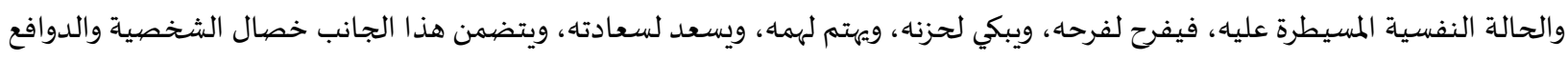

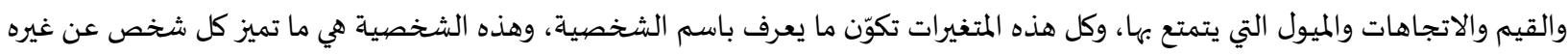
من الناس. الجانب الجمالي: ويقصد به تذوق شكل النص الأدبي، أي إدراك أثر كل جزئية من أجزاء النص، وإدراك العلاقات والتداخلات فيما بين هذه

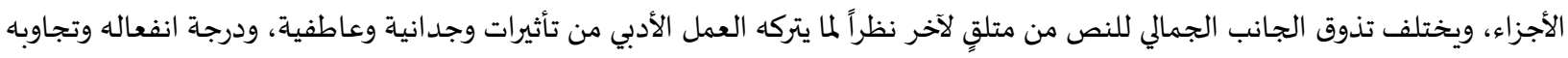
مع النص.

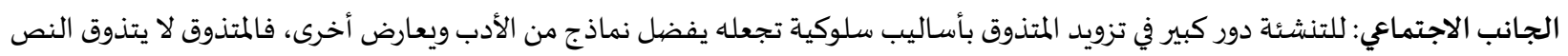

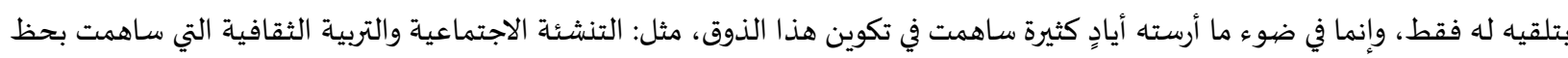
وافر في تكوين الشخصية.

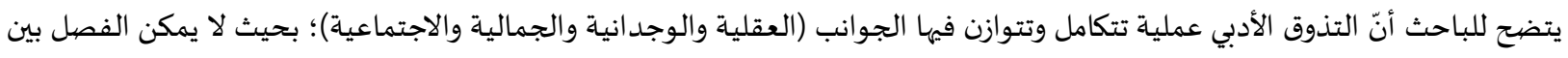

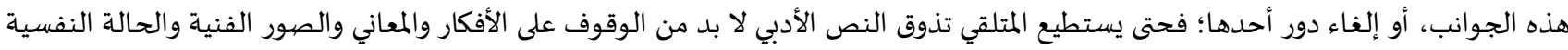


وفي ذات السياق يشير الخيري (2014) إلى أن العمل الأدبي مكون من مجموعة من الخصائص الفنية والجمالية المميزة له، والمتمثلة في الألفاظ

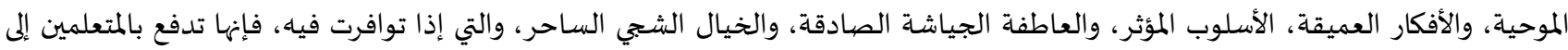
قراءته والميل لله وتذوقها والاستمتاع به. وهنا الباحث يؤكد على أن هذه العناصر من أهم عناصر تذوق النصوص الأدبية، التي على المعلم تذوق النصوص الأدبية في ضوئها، وتنميتها لدى الطلبة في مختلف المراحل؛ للوصول إلى تصور أعمق للنصوص المئه الأدبية، وفهم للمعاني، وادراك للعلاقات،

وألوان الجمال.

ولهذا ظهرت مجموعة من النظريات التي حاولت تفسير عملية التذوق الأدبي سواء من جانب المبدع كمتذوق، أو قارئ العمل الأدبي بوصفة

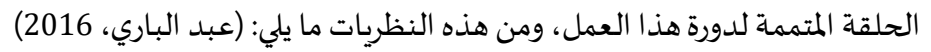

نظرية التفسير الإلهامي: فسر إبداع العمل الأدبي على أنه عمل ليس للمبدع القدرة على التحكم فيه أو ضبطه، أو حتى توجيها، ومن ثم فقد

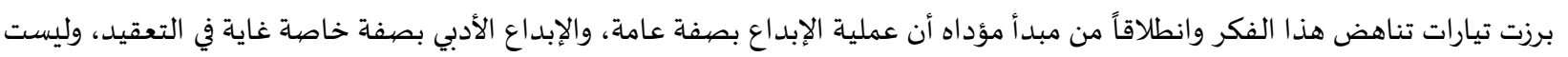
عملاً غفلاً كما تصوره الأقدمون. نظرية التحليل النفسي: فسرت حقيقة الإبداع من صميم الخبرات الشخصية للفنان، لذا سعت هذه النظرية لإثبات أن الأعمال الإبداعية ليست سوى تنفيس أو تسامي لرغبات مكبوتة. النظرية السلوكية: فسرت السلوك الإبداعي والتذوقي تفسيراً فسيولوجياً، حيث إن المجرب السيكولوجي في النظرية السلوكية يهتم بالسلوك الظاهر، وليس بالآلية الداخلية للسلوك، حيث نظرت إلى السلوك الخارجي بين كل من المبدع والمتلقي، وحاولت قدر جهدها أن تحقق قدورئ قدراً من الضبط التحكم في المثير (العمل الأدبي)، وكيف تحدث الاستجابة حول هذا العمل ألفائ أو ذاك.

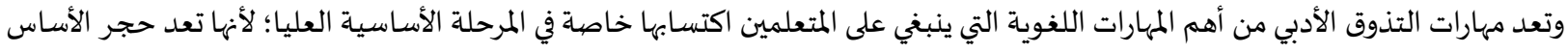

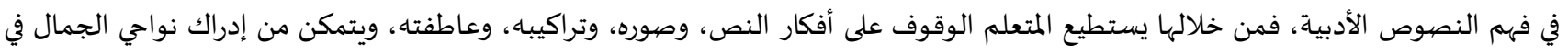

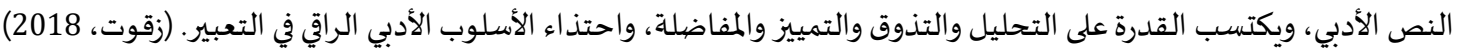
وقد حدد مدكور (2006) مهارات التذوق الأدبيّ بما يلي: تفسير النص الأدبي: وهي قدرة المتعلم على فهم معاني النص وفهم الأفكار المتضمنة، من خلال استحضيار العبارات التي تشمل على معان متشابهة لمعاني النص المسموع، وقدرته على تحديد دلالة الرموز الواردة في النص المسموع مع إبراز العناصر المختلفة المشكلة للنص من أفكار وأخيلة وصيور بيانية وألفاظ وأساليب، ومهمة المعلم أن يُدرب المتعلمين على هذه المهارة بالمناقشة والحوار حول الغامض من المعاني والأفكار الواردة في النص. الكشف عن الحركة النفسية في النص: وتعني قدرة المتعلم في الكشف عن الاتجاهات والانفعالات والعواطف النفسية للأديب، والقدرة على استخراج الصفات التي يصف بها الأديب نفسه أو غيره من الشخصيات التي تظهر في النص المسموع؛ وبذلك على المتعلم معايشة الظروف

$$
\text { والأحداث التي أحاطت بالأديب وأثرت فياء. }
$$

الإحساس بالجو انب الجمالية في النص: يختلف الإحساس والتذوق بالجوانب الجمالية من شخص لآخر نظراً لما يتركه العمل الأدبي من تأثير وجداني وعاطفي في نفس المتلقي، ففي هذا الجانب على المتعلم أن يستخرج المحسنات البديعية مع بيان أثرها وأهميتها على نفسـاه، وتحديد مواطن الجمال في النص المسموع. تحليل مضمون النص: حيث يقوم المتعلم في أثناء تحليله للنصوص بإجراء مفاضلة بين عمل وعمل آخر لنفس الأديب، أو لعمل آخر لأديب آخر في نفس الموضوع، مع إظهار عناصر الصهوت والحركة واللون الواردة في النص، والوقوف على الصور الفنية وتحليلها تحليلًا أدبيًا وافيًا. تقويم النص: وهي الأحكام التي يصدرها المتلقي، ويبدي الرأي فيها، وبيان مواطن التأثر والتأثير، والحكم على قدرة الأديب في إظهار تجربته. ومن العوامل التي تعيق تذوق النصوص؛ استخدام طرائق التدريس التي تعتمد على الحفظ والاستظهار دون مراعاة للفروق الفردية بين

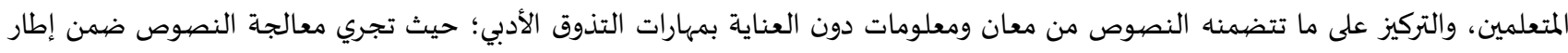

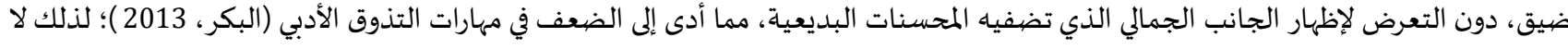

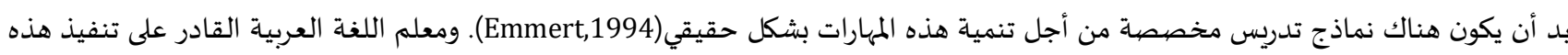
النماذج التدريسية لكن بحاجة إلى امتلاك مهارات التذوق الأدبي وممارستها، فالمعّلم طرف رئيس في هذا التواصل، وضعفه التهاء اللغوي عامل مؤثّر في نجاح

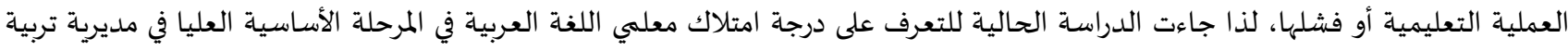

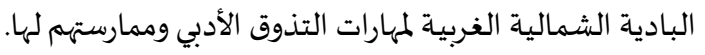


1.1. ت الدراسات السـابقة:

حظيت مهارات التذوق الأدبي باهتمام الدراسات والبحوث التربوية، ومنها: دراسـة الشهري وعتوم (2019) التي هدفت إلى التعرف على العلاقة بين الذكاء الانفعالي ومهارات التذوق الأدبي لدى معلمي اللغة العربية ومعلماتها في المرحلة الثانوية بمنطقة نجران، ولتحقيق أهداف الدراسة استخدم المنهج الوصفي التحليلي، وصمّما مقياس الذكاء الانفعالي الذي تكون من (38) فقرة، ومقياس التذوق الأدبي الذي تكون من (20) فقرة، ووُزّع المقياسان على عينة الدراسة البالغ عددها (105) معلماً ومعلمة. أظهرت النتائج أن مستوى الذكاء الانفعالي عند معلمي اللغة العربية ومعلماتها مرتفع، وأن مستوى مهارات التذوق الأدبي مرتفع أيضًا، كما أظهرت النتائج عدم وجود فروق دالة إحصائياً في مستوى الذكاء الانفعالي ومستوى التذوق الأدبي بشكل عام تعزى لمتغيرات الجنس، والمؤهل العلمي، وسنوات الخبرة، وبيّنت النتائج أيضا وجود علاقة ارتباطية بين الذكاء الانفعالي ومهارات التذوق الأدبي لدى معلمي اللغة العربية ومعلماتها في المرحلة الثانوية. وأجرى آل تميم (2015) دراسة هدفت التحقق من امتلاك طلاب الصف الثاني المتوسط بمكة المكرمة لمهارات التذوق الأدبي، وخلصت الدراسة إلى ما يأتي: إعداد قائمة بمهارات التذوق الأدبي المناسبة لطلاب الصف الثاني المتوسط ومنها: المهارات الخاصة بالمضيمون الفكري، المهارات المرتبطة بالعاطفة، المهارات التصويرية، المهارات الأسلوبية، المهارات اللغوية، وأظهرت النتائج تدنياً في مستوى طلاب الصف الثاني المتوسط في مهارات التذوق الأدبي عامة، وفي كل مهارة رئيسـة خاصية، إذ كانت جميع المهارات دون مستوى التمكن المطلوب من هذه المهارات جميعاً. وأجرى حسن (2015) دراسة هدفت تعرف مدى ممارسة مدَّرسي اللغة العربية لمهارات التذوق الأدبي في موضوعات الأدب والنصوص لدى طلبة الصف الرابع الأدبي في العراق، استخدم المنهج الوصفي عن طريق إعداد بطاقة ملاحظة تم تطبيقها على (40) مدرساً ومدَّرسة. توصلت الدِّراسة إلى عدة نتائج أهمها: أن ممارسة مدرسي اللغة العربية لمهارات التذوق الأدبي كانت متوسطة بشكل عام، كما تبين أنَّ هناك فروقاً ذات دلالة إحصائية عند مستوى الدلالة (a) 0.05$)$ في مدى الممارسة لمهارات التذوق الأدبي تبعاً لمتغير الجنس لصالح الإناث، وعدم وجود فروق ذات دلالة إحصائية عند مستوى الدلالة (ب=0.05 م) في مدى الممارسة تعزى لمتغير (المؤهل العلمي). وقام محممد (2013) بدراسة استهدفت التحقق من فاعلية برنامج لتنمية كفايات معلمي اللغة العربية في تحليل النص الأدبي، وأثره في إنماء مهارات التذوق الأدبي لدى طلاب المرحلة الثانوية بالإمارات، وأظهرت النتائج فاعلية برنامج تنمية كفايات تحليل النص الأدبي لدى معلمي اللغة العربية، وفاعلية هذا البرنامج في تنمية مهارات التذوق الأدبي لدى طلاب المرحلة الثانوية بالإمارات. وأجرى الشـيفات (2013) دراسة هدفت إلى تنمية مهارات التذوق الأدبي بالمستوى الإبداعي من خلال بناء برنامج تعليمي قائم على مهارات التذوق الأدبي بالمستوى الإبداعي من خلال تدريس نصوص أدبية لدى طلبة قسم اللغة العربية في كلية الآداب في الجامعة الهاشمية، وبيّنت نتائج الدراسة وجود فروق ذات دلالة إحصائية لأثر الطريقة في مهارتي التوسع والمرونة لصالح الطريقة التجريبية، وعدم وجود فروق ذات دلالة إحصائية في مهارتي الطلاقة والأصالة، أما مهارتا التوسع، والمرونة فقد وُجدت فروق ذات دلالة إحصائية لأثر التفاعل بين الطريقة, والجنس, وعدم وجود فروق ذات دلالة إحصائية تعزى لأثر الجنس في جميع المهارات. وأجرى مقداد (2008) دراسة هدفت إلى الكشف عن مستوى مهارات التذوق الأدبي لدى معلمي اللغة العربية بالمرحلة الأساسية العليا بقطاع

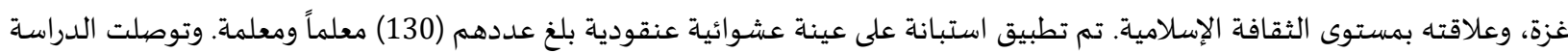
إلى وجود ضعف في مستوى التذوق الأدبي لدى المعلمين عينة الدراسـة، مع وجود فروق في مستوى مهارات التذوق الأدبي تعزى إلى متغير سنوات الخبرة لصالح المعلمين من فئة 5 سنوات فأكثر، وعدم وجود فروق في متغير الجنس، كما لا توجد علاقة بين مستوى مهارات التذوق الأدبي، ومستوى الثقافة الإسلامية لدى المعلمين عينة الدراسـة. وأجرى فلود ولاب (Flood \& Lapp, 2002) دراسـة هدفت إلى الكشف عن أثر القدرات القرائية العليا للطلبة والمتمثّلة بالقراءة الناقدة والإبداعية بمهارات التذوق الأدبي، وقد أظهرت النتائج ارتباطًا عاليًا بين نتائج الطلبة ذوي المهارات القرائية المتقدمة واستجاباتهم بمهارات التذوق الأدبي. وأجرت روزاريو (Rosario, 2001) دراسـة هدفت إلى الكشف عن إحساس طلبة المرحلة الثانوية في المدارس الأمريكية، الذين يدرسون اللغة

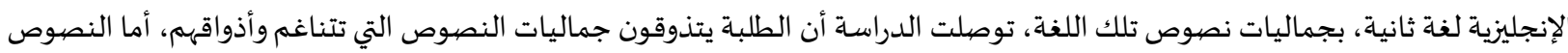
التي لا تنسجم ومشـاعرهم وأذواقهم ولا تتناسب وقدرات التعبير والتحليل لديهم، فإنهم يعزفون عنها، ولا يستطيعون فهمها، الأمر الذي ينعكس سلبًا على تذوقهم لها واحساسهم بما فيها من جمال. 
من خلال عرض الدِّراسات السَّابقة، يلاحظ توافقاً بينها والدِّراسة الحالية في تناولها موضوع مهارات التذوق الأدبي؛ إلا أنَّ الدِّراسة الحالية قد

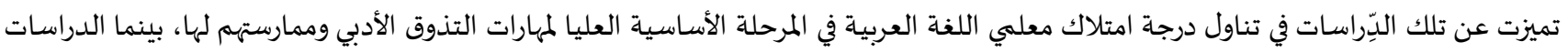
السابقة تناولت العلاقة بين مهارات التذوق الأدبي ومتغير آخر فمثلاً دراسـة الشهري وعتوم (2019) العلاقة بين الذكاء الانفعالي ومهارات التذوق الأدبي، ودراسة الشـيفات (2013) العلاقة بين مهارات التذوق الأدبي والمستوى الإبداعي، ودراسة مقداد (2008) العلاقة بين مهارات التذوق التهات الأدبي والثقافة الإسلامية.

2.1.

يرى الباحث أنه على الرغم من أهمية مهارات التذوق الأدبي إلا أن هناك ضعفاً وصعوبات تواجه الطلبة في المراحل التعليمية وبخاصة في المرحلة

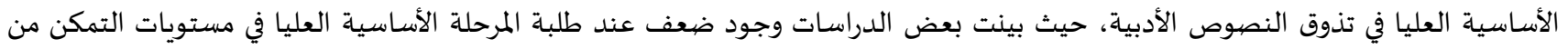

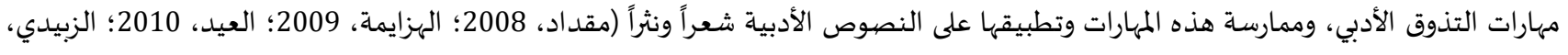

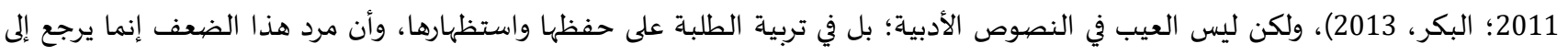

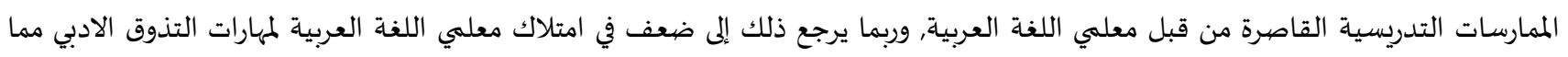

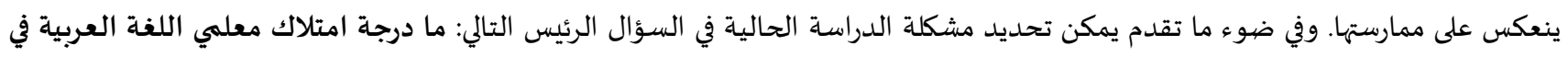

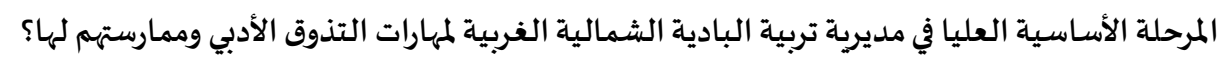

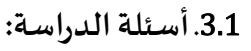

تحاول هذه الدراسة الاجابة عن الأسئلة الآتية:

1. ما درجة امتلاك معلمي اللغة العربية في المرحلة الأساسية العليا في مديرية تربية البادية الشمالية الغربية لمهارات التذوق الأدبة الأدبي؟

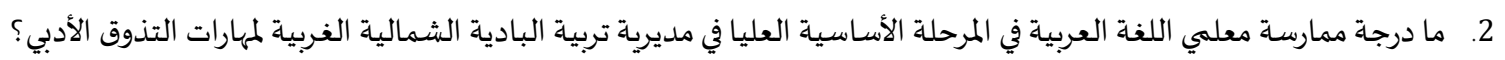

3. هل توجد علاقة ارتباطية بين درجة امتلاك معلمي اللغة العربية في المرحلة الأساسية العليا في مديرية تربية البادية الشمالية الغربية لمهارات

التذوق الأدبي وممارستهم لها؟ توجاد

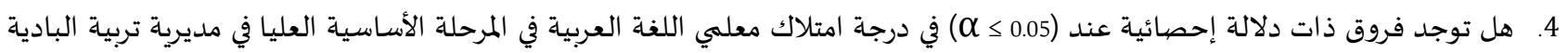

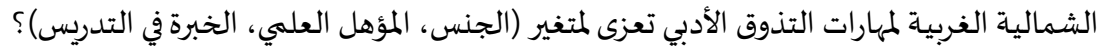

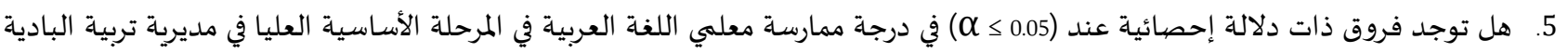

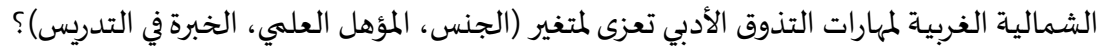

4.1 - 2.1 أهداف الدراسـة:

تهدف هذه الدراسـة إلى تحقيق ما يلي:

1. التعرف إلى درجة امتلاك معلمي اللغة العربية في المرحلة الأساسية العليا في مديرية تربية البادية الشمالية الغربية لمهارات التذوق الأدبي.

2.

3. الكشف عن وجود علاقة ارتباطيه بين درجة الامتلاك ودرجة الممارسة.

4. فحص دلالة الفروق بين متوسطات درجة امتلاك معلمي اللغة العربية في المرحلة الأساسية العليا في مديرية تربية البادية الشمالية الغربية

لمهارات التذوق الأدبي وممارستهم لها، وفقا لمتفيرات الجنس، والمؤهل العلمي، والخبرة في فئل التدريس.

5.1

تكمن أهمية الدراسة في بناء مقياس لمهارات التذوق الأدبي يتناسب مع البيئة العربية عموماً والأردنية خصيوصاً، وتقديم معلومات عن التذوق

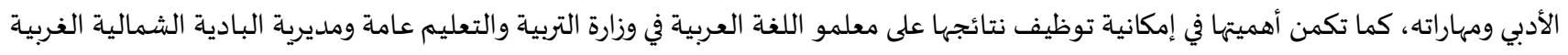

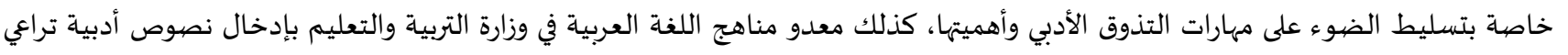

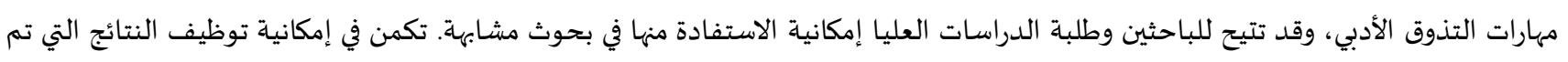
التوصل إليها في المدارس.

6.1. التعريفات الإجر ائية:

مهارات التذوق الأدبي: مجموعة من المهارات التي يتضمنها النص الأدبي، ويمتلكها معلمي اللغة العربية نتيجة تفاعلهم مع النص الأدبي لتقديره والحكم علياه حكمًا موضوعيًا ومن تلك المهارات إدراك الجمال اللغوي الذي يظهر في تعبيره عن مشاعره، والتفاعل العقلي والوجداني مع النص 
الأدبي، وقارئ ويتلق متذوق للعمل الأدبي، والتي يراعيها المعلم أثناء تدريسه. وتعرف إجر ائياً بأها: الدرجة التي حصل علهيا أفراد العينة في

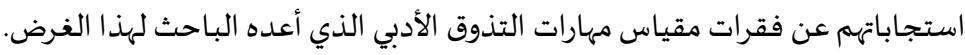

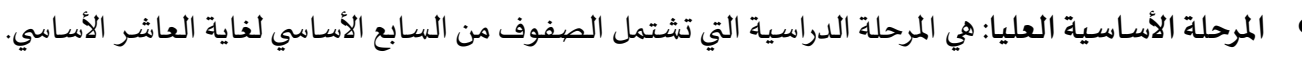

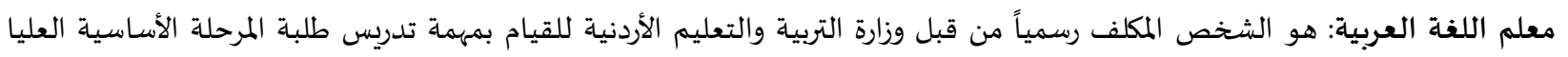
لمقررات المتعلقة باللغة العربية. 7.1. 7.1 حدود الدراسة ومحدداتها: ه الحدود الموضيوعية: اقتصرت الدِّراسة على امتلاك معلمي اللغة العربية لمهارات التذوق الأدبي وممارستهم لها من وجهة نظرهم. • الحدود المكانية: اقتصرت الدراسة على المدارس الأساسية الحكومية في البادية الشمالية الغربية.

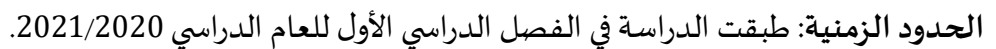
ه الحدود البشرية: اقتصرت الدراسة على معلمي اللغة العربية في المرحلة الأساسية العليا في مديرية تربية البادية الشمالية الغربية. • المحددات: يتحدد تعميم نتائج هذه الدِّراسة في ضوء الخصائص السيكومترية لأداة الدِّراسة، وكذلك بمدى موضوعية استجابة عينة الدِّراسة ل اللإجابة عن أداة الدِّراسة.

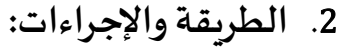

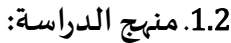
تم استخدام المنهج الوصفي الذي يصف الظاهرة كما هي في الواقع، نظراً لمناسبته في تحقيق أهداف الدِّراسة الحالية والإجابة عن أسئلتها، والتي تستخدم أداة لجمع البيانات، حيث تم جمع البيانات الكمية عن طريق الاستبانة، إضافة إلى سهولة فهم الظاهرة وفق هذا المنهج وبالتالي سهولة

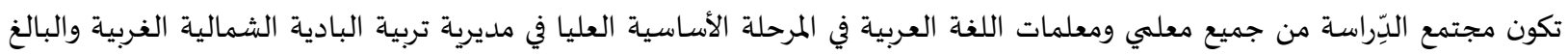

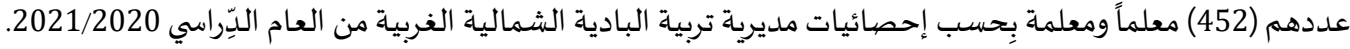

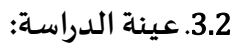

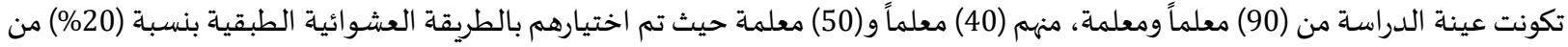

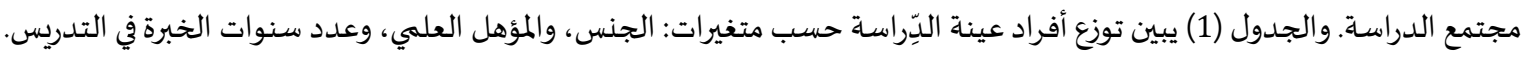
جدول (1): توزع أفراد عينة الدِّراسة حسب متغيراتها

\begin{tabular}{|c|c|c|c|}
\hline النسبة المئوية & العدد العد & الفئات & المتغير \\
\hline$\% 44$ & 40 & ذكور & الجنس \\
\hline$\% 56$ & 50 & إناث & \\
\hline$\% 100$ & 90 & & \\
\hline$\% 58$ & 52 & بكالوريوس & المؤهل العلمي \\
\hline$\% 42$ & 38 & دراسات عليا & \\
\hline$\% 100$ & 90 & & \\
\hline$\% 48$ & 43 & أقل من 5 سنوات & عدد سنوات الخبرة \\
\hline$\% 52$ & 47 & 5 سنوات فأكثر & \\
\hline$\% 100$ & 90 & & \\
\hline
\end{tabular}

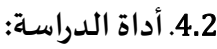
في ضوء مراجعة الأدب التربوي والدِّراسات السابقة وأدواتها المتعلقة بموضوع الدِّراسة، مثل دراسة الشهري وعتوم (2019)، وآل تميم (2015)،

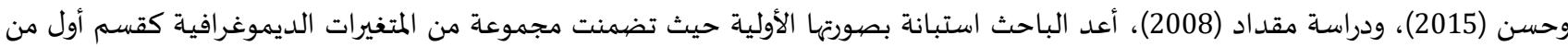

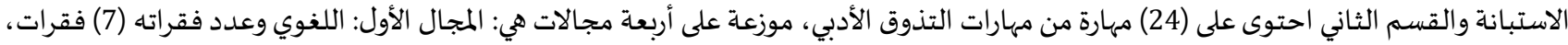

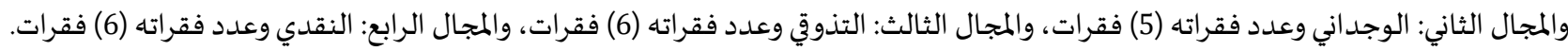




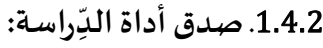

للتحقق من صدق أداة الدراسة؛؛ تمّ عرضها بصيفتها الأولية على مجموعة من المحكمين من ذوي الاختصاص في المناهج وطرائق تدريس اللغة

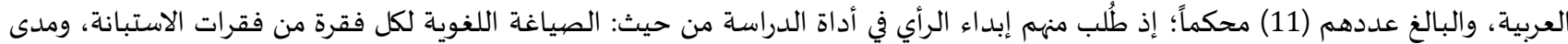

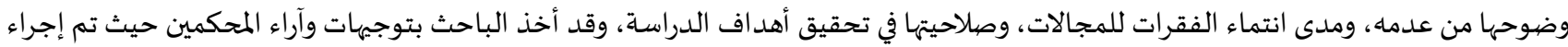
بعض التعديلات اللغوية، وحذف ثلاث فقرات لتصبح الاستبانة بعد التحكيم بصورتها النهائية مكونة من (21) فقرة موزعة على أربعة مجالات. 2.4.2 ثبات أداة اللَّراسـة: للتحقق من ثبات أداة الدراسـة؛ تمّ تطبيقها على عينة استطلاعياة من مجتمع الدراسة مكونة من (25) معلماً ومعلمة من خارج عينة الدراسـة، ثمّ

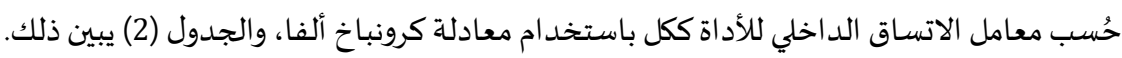
جدول (2): معامل الاتساق الداخلي (كرونباخ ألفا) لمجالات أداة الدِّراسة

\begin{tabular}{|c|c|c|}
\hline معامل الثبات & عدد الفقرات & المجال \\
\hline 0.86 & 7 & اللغوي \\
\hline 0.83 & 4 & الوجداني \\
\hline 0.81 & 5 & التذوقي \\
\hline 0.88 & 5 & النقدي \\
\hline 0.92 & 21 & للأداة ككل \\
\hline
\end{tabular}

ويتبين من الجدول (2) أن قيم معامل الاتساق الداخلي لمجالات الدِّراسة، وفقاً لمعادلة كرونباخ ألفا كانت قيم مقبولة لأغراض الدِّراسـة ويمكن

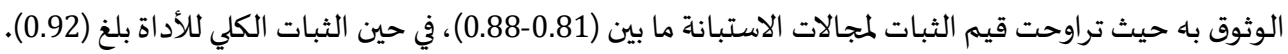
3.4.2 طريقة تصحيح أداة الدِّراسـة: أعطيت فقرات الاستبانة بحسب تدريج ليكرت الخماسي (Likert) في التصحيح على النحو الآتي: درجة (1) قليلة جداً، ودرجة قليلة (2)، ودرجة (3) متوسطة، ودرجة (4) عالية، ودرجة (5) عالية جداً، ثم اعتمد المتوسطات الحسابية لإجابات أفراد العينة لتكون مؤشراً على درجة التقدير

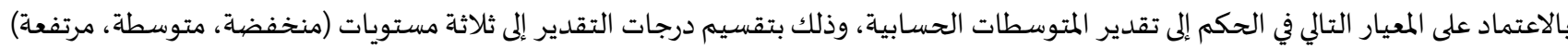
حسب متوسطات إجابات العينة لكل فقرة فتصبح بعد ذلك التقديرات كالآتي: (1-2.33) بدرجة منخفضيةً، (2.34-3.67) بدرجة متوسطة، (3.68-5) بلدرجة مرتفعة. 5.2 إجراءات تنفيذ الدِّراسـة:

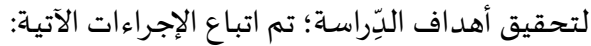
الاطلاع على الأدب التربوي والدِّراسـات السابقة ذات الصلة بالدِّراسـة وتحديد مشكلة الدِّراسـة ثم إعداد أداة الدِّراسة بصورتها الأولية ثم التحقق من صددق أداة الدِّراسة وثباتها بعد عرضها على المحكمين وتطبيقها على عينة استطلاعية وإجراء التعديلات اللازمة لتصبح أداة الدِّراسة بصورتها الهائية. تم أخذ الموافقة الرسمية على تطبيق أداة الدِّراسـة ثم توزيع أداة الدِّراسة على أفراد عينة الدِّراسة ثم بعد مدة زمنية جرى استرجاع الاستبانات. ترميز الإجابات لكل استبانة، وإدخال البيانات إلى ذاكرة الحاسوب باستخدام برنامج (spss) لمعالجتها إحصائياً، وإجراء التحليلات الإحصائية اللازمة للإجابة عن أسئلة الدِّراسة وتفسيرها.

6.2. للإجابة عن أسئلة الدِّراسة تم اعتماد الأسـاليب الإحصائية المناسبة لتحليل البيانات باستخدام برنامج (SPSS)، إذ تم استخدام المتوسطات الحسابية، والانحرافات المعيارية، والنسب المئوية، والرتب، للإجابة عن السؤال الأول والثاني، ولإجابة عن السؤال الثالث تم استخدام معامل ارتباط بيرسون لحساب قوة العلاقة واتجاهها، ولإجابة عن السؤال الرابع والخامس تم استخدام المتوسطات الحسابية، والانحرافات المعيارية، وتحليل التباين المتعدد.

3. عرض النتائج ومناقشتها: 1.3. النتائج المتعلقة بالسؤال الأول ومناقشتها: ما درجة امتلاك معلهي اللغة العربية في المرحلة الأساسية العليا في مديرية تربية البادية الشمالية

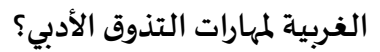


للإجابة عن هذا السؤال، تمَّ حساب المتوسطات الحسابية والانحرافات المعيارية لكل مجال، وتصنيف درجة الامتلاك إلى منخفضية، أو متوسطة أو مرتفعة حسب المعيار المستخدم في الدراسة، والجدول هدول (3) يبين ذلك. جدول (3): المتوسطات الحسابية والانحر افات المعيارية لاستجابات أفراد العينة على مجالات مهارات التذوق الأدبي

\begin{tabular}{|c|c|c|c|c|c|c|}
\hline درجة الامتلاك & النسبة المئوية & الانحراف المعياري & المسابي & المجال & رقم المجال & الرتبة \\
\hline مرتفعة & \%73.6 & 0.84 & 3.68 & التذوقي & 3 & 1 \\
\hline متوسطة & $\% 72.8$ & 0.82 & 3.64 & الوجداني & 2 & 2 \\
\hline متوسطة & \%71.8 & 0.76 & 3.59 & اللغوي & 1 & 3 \\
\hline متوسطة & $\% 70$ & 0.86 & 3.50 & النقدي & 4 & 4 \\
\hline متوسطة & $\% 72$ & 0.76 & 3.60 & & \multicolumn{2}{|c|}{ الدرجة الكلية } \\
\hline
\end{tabular}

يبين الجدول (3) أن درجة امتلاك معلمي اللغة العربية في المرحلة الأساسية العليا في مديرية تربية البادية الشمالية الغربية لمهارات التذوق الأدبي

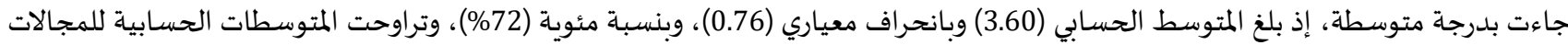

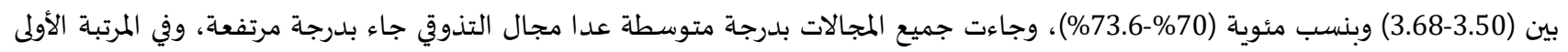
بمتوسط حسابي بلغ (3.68)، وانحراف معياري مقداره (0.84)، وبنسبة مئوية (73.6\%)، تلاه في المرتبة الثانية المجال الوجداني بمتوسط حسابي بلغ

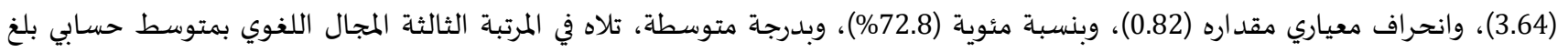
(3.59)، وانحراف معياري مقداره (0.76)، وبنسبة مئوية (71.8\%)، وبدرجة ماندة متوسطة، وأخيراً جاء المجال النقدي بالمرتبة الأخيرة بمتوسط حسـابي بلغ

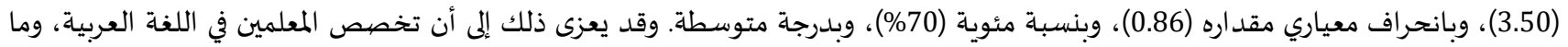

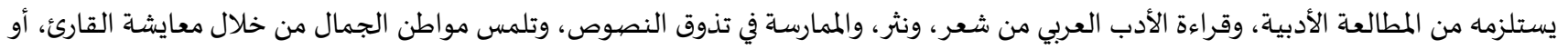
السامع، فالمعلم تغير دوره، ولم يعد ملقنًا، فيظهر دوره في تنمية التذوق الأدبي لدى طلبته من خلال إيمانه بأن كل طالب لدية القدرة على التذوق ملأله

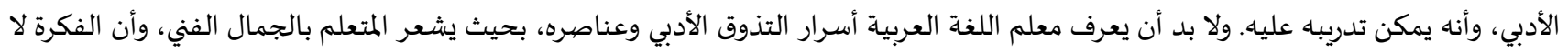

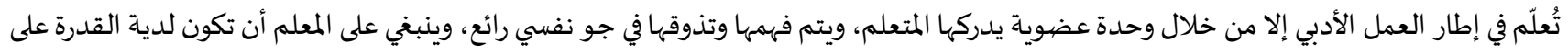

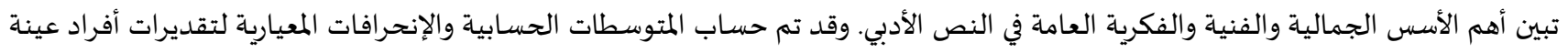
الدراسة على فقرات كل مجال من مجالات مهارات التذوق الأدبي على حده، حيث كانت على النحو الآتي: : المجال الأول: المجال اللغوي:

جدول (4): المتوسطات الحسابية والإنحر افات المعيارية لفقرات المجال اللغوي مرتبة تنازلياً

\begin{tabular}{|c|c|c|c|c|c|c|}
\hline الامتلاك درجة & المئوية & الالمحراف & المتوسطابي & المهارات & رقمم & 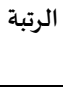 \\
\hline 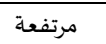 & $\% 74.6$ & 0.90 & 3.73 & استنتاج المعاني الضمنية في النص الأدبي. & 1 & 1 \\
\hline 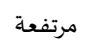 & $\% 73.8$ & 0.84 & 3.69 & تفسير معاني المفردات في سياق النص الأدبي. & 3 & 2 \\
\hline 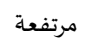 & $\% 73.6$ & 0.92 & 3.68 & تحديد الأفكار الفرعية في النص الأدبي. . & 5 & 3 \\
\hline 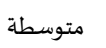 & $\% 72.4$ & 1.03 & 3.62 & تحديد الأفكار الرئيسة في النص الأدبي. & 4 & 4 \\
\hline متوسطة & $\% 69.6$ & 0.91 & 3.48 & يحدد عبارة ضمن النص الأدبي تصلح حكمة أو مثلًا. & 7 & 5 \\
\hline متوسطة & $\% 69.4$ & 0.98 & 3.47 & يضع عنوانًا مناسبًا للنص الأدبي. & 6 & 6 \\
\hline متوسطة & $\% 68.8$ & 0.91 & 3.44 & تفسير معنى التركيب أو العبارة في النص الأدبي. & 2 & 7 \\
\hline متوسطة & \%71.8 & 0.76 & 3.59 & الدرجة الكلية & & \\
\hline
\end{tabular}

يبين الجدول (4) أن تقديرات أفراد عينة الدراسة لدرجة امتلاكهم للمجال اللغوي كانت متوسطة بمتوسط حسابي بلغ (0.59)، وانحراف

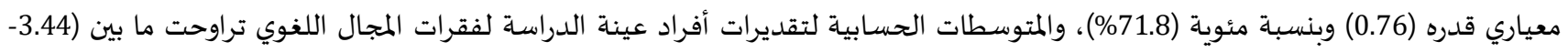
3.73)، حيث جاءت الفقرة (1) ونصيها " استنتاج المعاني الضمنية في النص الأدبي" في المرتبة الأولى بمتوسط حسابي بلغ (3.73) وانحراف معياري قدره

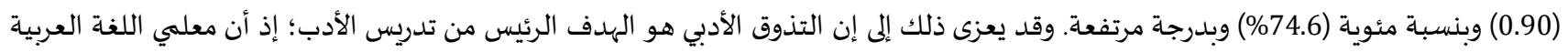

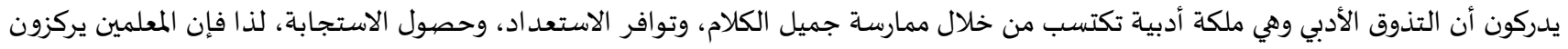

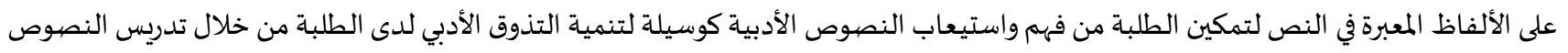
الأدبية، وبالتالي استنتاج المعاني الضمنية في النصوص الأدبية. في حين جاءت الفقرة (2) ونصها " تفسير معنى التركيب أو العبارة في النص الأدبي " بالمرتبة الأخيرة بمتوسط حسابي قدره (3.44) وانحراف معياري قدره (0.91) وبنسبة مئوية (68.8\%) وبدرجة متوسطة. وقد وقد يعزى ذلك إلى أن معلمي

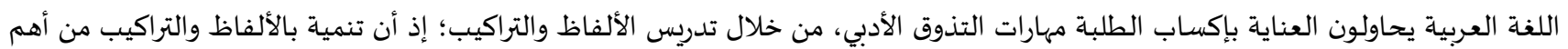
أهد اف تدريس الأدب. 
جدول (5): المتوسطات الحسابية والإنحر افات المعيارية لفقرات المجال الوجداني مرتبة تنازلياً

\begin{tabular}{|c|c|c|c|c|c|c|}
\hline الامتلاك درجة & المئوية & الانحراف & المتوسط الحسابي & 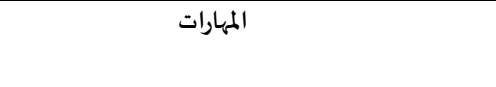 & الفقرة & 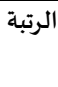 \\
\hline 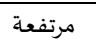 & \%74.8 & 0.94 & 3.74 & تحديد الحالة النفسية للأديب من سياق النص الأدبي. & 8 & 1 \\
\hline 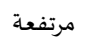 & $\% 74$ & 0.91 & 3.70 & تحديد مدى نجاح الأديب في التعبير عن حالته النفسية. & 10 & 2 \\
\hline متوسطة & $\% 72.8$ & 0.98 & 3.64 & تحديد العواطف السـائدة في النص الأدبي. & 9 & 3 \\
\hline متوسطة & $\% 69.4$ & 0.95 & 3.47 & تحديد دلالة التكرار في النص الأدبي. & 11 & 4 \\
\hline متوسطة & $72.8 \%$ & 0.82 & 3.64 & الدرجة الكلية & & \\
\hline
\end{tabular}

يبين الجدول (5) أن تقديرات أفراد عينة الدراسة لدرجة امتلاكهم للمجال الوجداني كانت متوسطة بمتوسط حسابي بلغ (3.64)، واندراف (0.82) وان معياري قدره (0.82) وبنسبة مئوية (72.8\%)، والمتوسطات الحسابية لتقديرات أفراد عينة الدراسة لفقرات المجال الوجدات اني تراوحت ما بين (3.47-

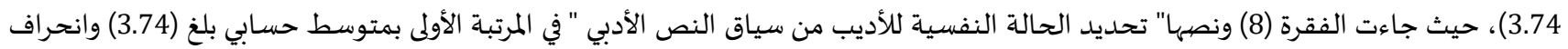

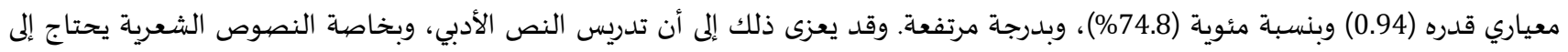

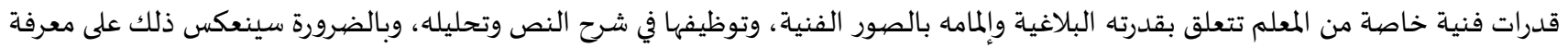

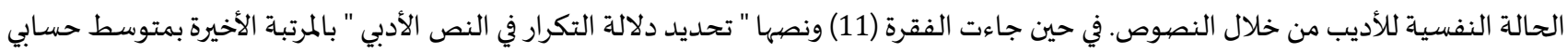
قدره (3.47) وانحراف معياري قدره (0.82) وبنسبة مئوية (69.4\%)، وبدرجة متوسطة. وقد يعزى ذلك إلى ضعف اهتبات اهتمام المعلمين بهذه المهارة؛ لأن

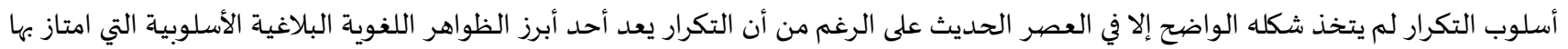

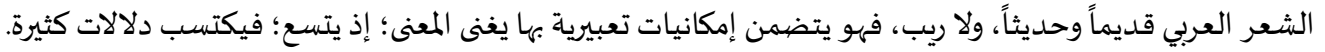

المجال الثالث: المجال التذوقي:

جدول (6): المتوسطات الحسابية والإنحر افات المعيارية لفقرات المجال التذوقي مرتبة تنازلياً

\begin{tabular}{|c|c|c|c|c|c|c|}
\hline 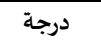 & 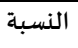 & 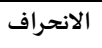 & المتوسط & 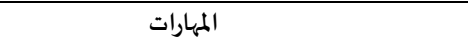 & 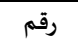 & 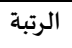 \\
\hline 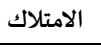 & 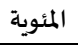 & 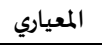 & 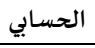 & & 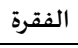 & \\
\hline 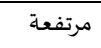 & 76.2 & 0.91 & 3.81 & تحديد النوع الأدبي الذي ينتمي إليه النص الأدبي. & 15 & 1 \\
\hline مرتفعة & 74.4 & 0.92 & 3.72 & يوضح رسم شخصيات النص. & 16 & 2 \\
\hline مرتفعة & 73.8 & 0.99 & 3.69 & يحدد دلالات الفنون البلاغية ( بيان، ومعاني، وبديع) & 14 & 3 \\
\hline متوسطة & 72.6 & 0.88 & 3.63 & توضيح الصور الفنية في النص الأدبي. & 13 & 4 \\
\hline متوسطة & 70.4 & 1.09 & 3.52 & تمييز الفكرة الأجمل في النص الأدبي. & 12 & 5 \\
\hline 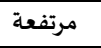 & 73.6 & 0.84 & 3.68 & 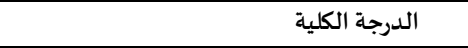 & & \\
\hline
\end{tabular}

يبين الجدول (6) أن تقديرات أفراد عينة الدراسة لدرجة امتلاكهم للمجال التذوقي كانت مرتفعة بمتوسط حسابي بلغ (3.68)، وانحراف معياري

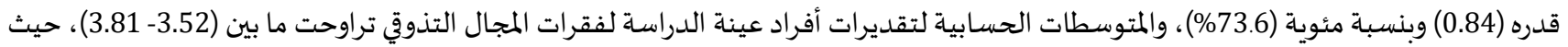
جاءت الفقرة (15) ونصها " تحديد النوع الأدبي الذي ينتمي إليه النص الأدبي" في المرتبة الأولى بمتوسط حسابي بلغ (3.81) وانحراف معياري قدره (0.91) وبنسبة مئوية (76.2\%)، وبدرجة مرتفعة. وقد يعزى ذلك إلى أن إطلاع بعض المعلمين على الأعمال الفنية للمبدعين من شعراء والكتاب خلال

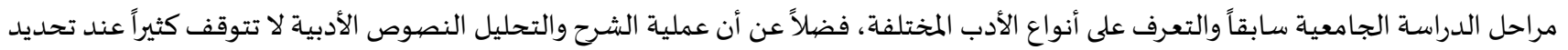
جوانب الجمل في النصوص الأدبية، إنما يتعدى ذلك إلى تناول النوع الأدبي. في حين جاءت الفقرة الفئ (12) ونصها " تمييز الفكرة الأجمل في النص الأدبي"

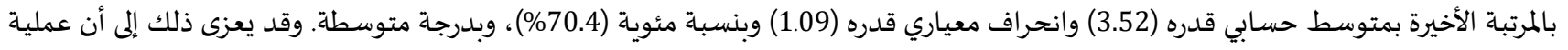
تحديد مواطن الجمال بشكل عام، والفكرة بشكل خاص، قد لا يجد العناية الكافية من المعلم عند شرح النص الأدبي أو تحليله، فهي قد تركز على لهم

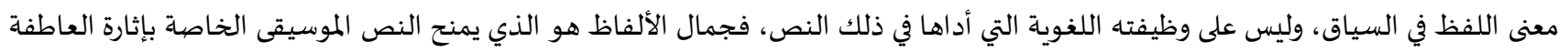
لدى الطالب، وبالنتيجة التمكن من تحديد مواطن ذلك الجمال. 
•

جدول (7): المتوسطات الحسابية والإنحر افات المعيارية لفقرات المجال النقدي مرتبة تنازلياً

\begin{tabular}{|c|c|c|c|c|c|c|}
\hline درجة & النسبة & الانحراف & المتوسط & المهارات & رقم & الرتبة \\
\hline الامتلاك & المئوية & المعياري & الحسابي & & الفقرة & \\
\hline مرتفعة & $\% 74.8$ & 0.95 & 3.74 & تحديد مواطن التأثر بالنص الأدبي. & 17 & 1 \\
\hline 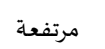 & \%73.6 & 1.06 & 3.68 & التمييز بين الحقيقة والخيال في النص الأدبي. & 18 & 2 \\
\hline متوسطة & $\% 68.6$ & 0.97 & 3.43 & إصدار حكم على أسلوب الأديب في النص الأدبي. & 20 & 3 \\
\hline متوسطة & $\% 67.4$ & 0.93 & 3.37 & التمييز بين الدلالة الحقيقية والمجازية في النص الأدبي. & 21 & 4 \\
\hline متوسطة & $\% 65.2$ & 1.04 & 3.26 & التمييز بين الأسباب والنتائج في النص الأدبي. المبائ & 19 & 5 \\
\hline متوسطة & $\% 70$ & 0.86 & 3.50 & الدرجة الكلية & & \\
\hline
\end{tabular}

يبين الجدول (7) أن تقديرات أفراد عينة الدراسـة لدرجة امتلاكهم للمجال النقدي كانت متوسطة بمتوسط حسابي بلغ (3.50)، وانحراف معياري قدره (0.86)، والمتوسطات الحسابية لتقديرات أفراد عينة الدراسة لفقرات المجال النقدي تراوحت ما بين (3.26- 3.74) وبنسبة مئوية (70\%)، (17)، حيث جاءت الفقرة (17) ونصها " تحديد مواطن التأثر بالنص الأدبي" في المرتبة الأولى بمتوسط حسابي بلغ (3.74) وانحراف معياري قدره (0.95)

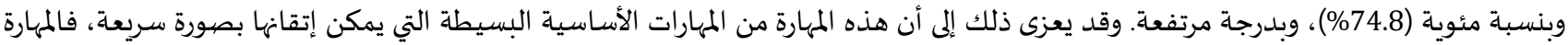
أقرب للفهم، وتحتاج لفهم النص دون الغوص في الجوانب النقدية أو البلاغية العميقة. في حين جاءت الفقرة (19) ونصها " التمييز بين الأسباب

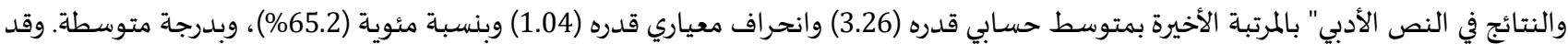
يعزى ذلك إلى أن هذه المهارة تعتبر من أكثر المهارات دقة، وتحتاج إلى إدراك قوي للعلاقات داخل النص الأدبي وتذوق ما قد ينتج عن هذه العلاقات من

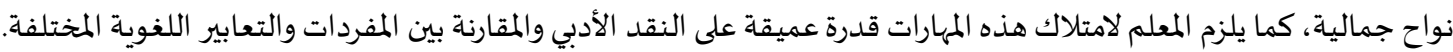

2.3. النتائج المتعلقة بالسؤال الثاني ومناقشتها: ما درجة ممارسة معلمي اللغة العربية في المرحلة الأساسية العليا في مديرية تربية البادية الشمالية الغربية لمهارات التذوق الأدبي؟ للإجابة عن هذا السؤال، تمَّ حساب المتوسطات الحسابية والانحرافات المعيارية لكل مجال، وتصنيف درجة الممارسة إلى منخفضية، أو متوسطة أو مرتفعة، والجدول (8) يبين ذلك. جدول (8): المتوسطات الحسابية والانحر افات المعياربة لاستجابات أفراد العينة على مجالات ممارسة مهارات التذوق الأدبي

\begin{tabular}{|c|c|c|c|c|c|c|}
\hline \multirow[t]{2}{*}{ درجة الممارسة } & النسبة & الانحراف المعياري & المتوسط الحسابي & المجال & رقم & الرتبة \\
\hline & المئوية & & & \multicolumn{3}{|c|}{ المجال } \\
\hline متوسطة & $\% 72.4$ & 0.51 & 3.62 & اللغوي & 1 & 1 \\
\hline متوسطة & $\% 72.2$ & 0.76 & 3.61 & الوجداني & 2 & 2 \\
\hline متوسطة & $\% 71.2$ & 0.75 & 3.56 & التذوقي & 3 & 3 \\
\hline متوسطة & $\% 70.2$ & 0.54 & 3.51 & النقدي & 4 & 4 \\
\hline متوسطة & $\% 71.6$ & 0.45 & 3.58 & الدرجة الكلية & & \\
\hline
\end{tabular}

يبين الجدول (8) أن درجة ممارسة معلمي اللفة العربية في المرحلة الأساسية العليا في مديرية تربية البادية الشمالية الغبربية لمهارات التذوق الأدبي جاءت بدرجة متوسطة، إذ بلغ المتوسط الحسابي (3.58) وبانحراف معياري (0.45) وبنسبة مئوية (71.6\%)، وجاءت جميع المجالات بدرجة

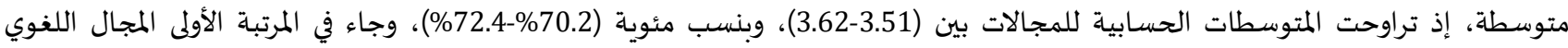

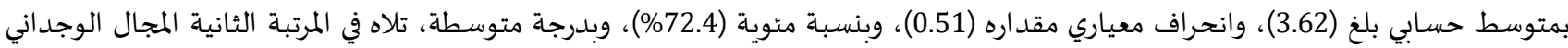
بمتوسط حسابي بلغ (3.61)، وانحراف معياري مقداره (0.76)، وبنسبة مئوية (72.2\%)، وبدرجة متوسطة، تلاه في المرتبة الثالثة المجال التذوقي

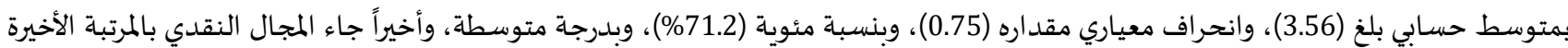
بمتوسط حسابي بلغ (3.51)، وبانحراف معياري مقداره (0.54)، وبنسبة مئوية (70.2\%)، وبدرجة متوسطة. وقد يعزى ذلك إلى أن للمعلم دور في تنمية

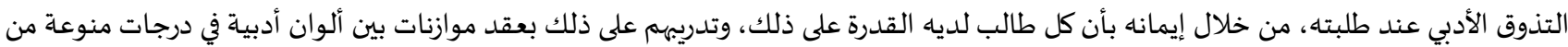
الجودة، وتقويم مد اها في كل لون، مع ضرورة توافر الحاسة الأدبية عند المعلم أثناء قراءته للنص الأدبي قراءة جهرية، فالمتعلم يتأثر بأداء المعلم، كما

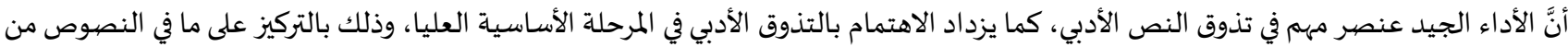
عواطف ومكونات جمالية ووجد انية؛ حيث يكون الطالب قد وصل نوعاً ما إلى مستوى معين من النضيج في كافة الجوانب العقلية والجسمية والانفعالية

واللغوية؛؛ فيهتم بدراسـة مختلف الألوان الأدبية، وتتطور قدرتاه على تحليل النصوص وتفسيرها ونقدها. وتتفق نتيجة هذا السؤال مع دراسة حسن (2015) التي توصلت إلى أنَّ ممارسة مدَّرسي اللغة العربية لمهارات التذوق الأدبي لدى طلبة الصفي الرابع الأدبي كانت متوسطة بشكل عام. واختلفت نتيجة هذا السؤال مع دراسة الشهري وعتوم (2019) التي أظهرت نتائجها أن مستوى مهارات التذوق 
الأدبي مرتفع، ودراسة مقداد (2008) التي توصلت إلى وجود ضعف في مستوى التذوق الأدبي لدى المعلمين. وقد تم حساب المتوسطات الحسابية

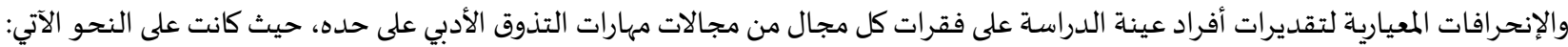

جدول (9): المتوسطات الحسابية والإنحر افات المعيارية لفقرات المجال اللغوي مرتبة تنازلياً

\begin{tabular}{|c|c|c|c|c|c|c|}
\hline 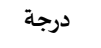 & النسبة & 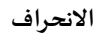 & المتوسط & 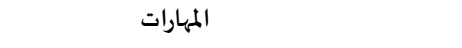 & 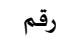 & 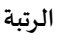 \\
\hline المممارسة & المئوية & المعياري & الحسابي & & الفقرة & \\
\hline 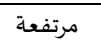 & $\% 77.6$ & 0.91 & 3.88 & تفسير معنى التركيب أو العبارة في النص الأدبي. & 2 & 1 \\
\hline 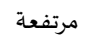 & $\% 76.8$ & 0.92 & 3.84 & تحديد الأفكار الفرعية في النص الأدبي. & 5 & 2 \\
\hline 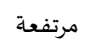 & 575.4 & 1.02 & 3.77 & تفسير معاني المفردات في سياق النص الأدبي. & 3 & 3 \\
\hline 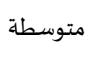 & $\% 72$ & 0.87 & 3.60 & استنتاج المعاني الضمنية في النص الأدبي. & 1 & 4 \\
\hline 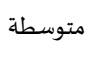 & $\% 71.8$ & 0.80 & 3.59 & تحديد الأفكار الرئيسة في النص الأدبي. & 4 & 5 \\
\hline 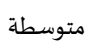 & $\% 67.8$ & 0.98 & 3.39 & يضع عنوانًا مناسبًا للنص الأدبي. & 6 & 6 \\
\hline متوسطة & $\% 65.8$ & 0.93 & 3.29 & يحدد عبارة ضمن النص الأدبي تصلح حكمة أو مثلًا. & 7 & 7 \\
\hline متوسطة & $\% 72.4$ & 0.51 & 3.62 & الدرجة الكلية & & \\
\hline
\end{tabular}

يبين الجدول (9) أن تقديرات أفراد عينة الدراسـة لدرجة ممارستهم للمجال اللغوي كانت متوسطة بمتوسط حسابي بلغ (3.62)، وانحراف معياري قدره (0.51)، وبنسبة مئوية (72.4\%)، والمتوسطات الحسابية لتقديرات أفراد عينة الدراسة لفقرات المجات المال اللغوي تراوحت ما بين (3.29-

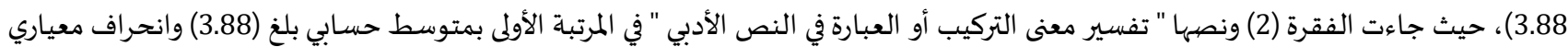

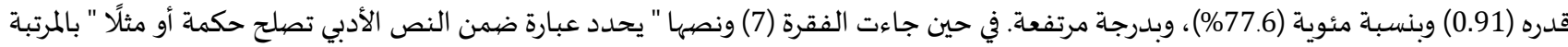

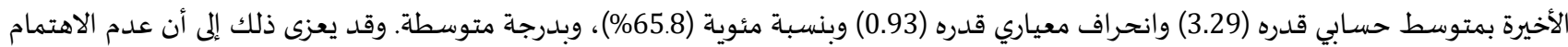
بتذوق النصوص الأدبية، والاقتصار في معظم الوقت على الجانب اللغوي متمثلاً في الشرح المعجمي والدلالي للمفردات اللغوية، أو بالتركيز على الجانب العقلي بتحديد أفكار النص الأدبي.

جدول (10): المتوسطات الحسابية والإنحر افات المعيارية لفقرات المجال الوجداني مرتبة تنازلياً

\begin{tabular}{|c|c|c|c|c|c|c|}
\hline 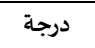 & 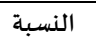 & 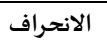 & المتوسط & 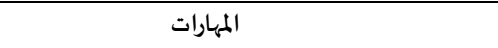 & 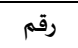 & 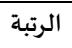 \\
\hline 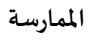 & 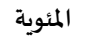 & 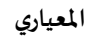 & 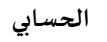 & & 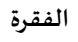 & \\
\hline 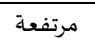 & $\% 76.2$ & 0.99 & 3.81 & تحديد العواطف السائدة في النص الأدبي. & 9 & 1 \\
\hline 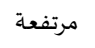 & $\% 75.2$ & 0.98 & 3.76 & تحديد مدى نجاح الأديب في التعبير عن حالته النفسية. & 10 & 2 \\
\hline متوسطة & $\% 71.6$ & 0.94 & 3.58 & تحديد دلالة التكرار في النص الأدبي. & 11 & 3 \\
\hline متوسطة & $\% 66$ & 0.99 & 3.30 & تحديد الحالة النفسية للأديب من سياق النص الأدبي. & 8 & 4 \\
\hline متوسطة & $\% 72.2$ & 0.76 & 3.61 & الدرجة الكلية & & \\
\hline
\end{tabular}

يبين الجدول (10) أن تقديرات أفراد عينة الدراسـة لدرجة ممارستهم للمجال الوجداني كانت متوسطة بمتوسط حسابي بلغ (3.61)، وانحراف معياري قدره (0.76)، وبنسبة مئوية (2.2\%)، والمتوسطات الحسابية لتقديرات أفراد عينة الدراسة لفقرات المجال الوجداني ترانية تراوحت ما بين (3.30-

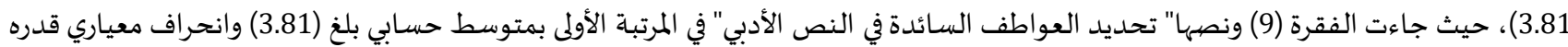
(0.99) وبنسبة مئوية (76.2\%)، وبدرجة مرتفعة. في حين جاءت الفقرة (8) ونصها " تحديد الحالة النفسية للأديب من سياق النص الأدبي" بالمرتبة

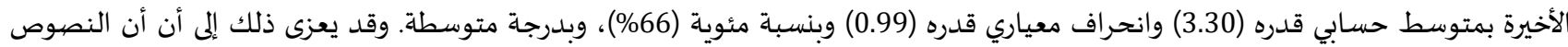
الأدبية المطروحة في كتاب اللغة العربية لا تخلو من العاطفة، مما يدفع المعلمين إلى استخدام عمليات تذوق النص القائمة على عاطفة المتلقي

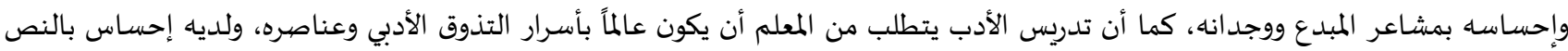

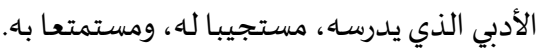


جدول (11): المتوسطات الحسابية والإنحر افات المعيارية لفقرات المجال التذوقي مرتبة تنازلياً

\begin{tabular}{|c|c|c|c|c|c|c|}
\hline الممارسة درجة & المئوية & المعياري & المسابي & 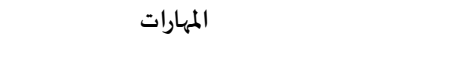 & الفقرة & الرتبة \\
\hline مرتفعة & $\% 75.4$ & 1.06 & 3.77 & تمييز الفكرة الأجمل في النص الأدبي. & 12 & 1 \\
\hline 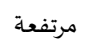 & $\% 73.8$ & 1.02 & 3.69 & توضيح الصور الفنية في النص الأدبي. & 13 & 2 \\
\hline متوسطة & $\% 72$ & 1.04 & 3.60 & تحديد النوع الأدبي الذي ينتمي إليه النص الأدبي. & 15 & 3 \\
\hline متوسطة & $\% 68.8$ & 0.93 & 3.44 & يوضح رسم شخصيات النص. & 16 & 4 \\
\hline متوسطة & $\% 66$ & 0.91 & 3.30 & يحدد دلالات الفنون البلاغية (بيان، ومعاني، وبديع) & 14 & 5 \\
\hline متوسطة & $\% 71.2$ & 0.75 & 3.56 & الدرجة الكلية & & \\
\hline
\end{tabular}

يبين الجدول (11) أن تقديرات أفراد عينة الدراسة لدرجة ممارستهم للمجال التذوفي كانت متوسطة بمتوسط حسابي بلغ (3.56)، وانحراف معياري قدره (0.75)، وبنسبة مئوية (71.2\%)، والمتوسطات الحسابية لتقديرات أفراد عينة الدراسة لفقرات المجال التذوقي تراوحت ما بين (3.30-

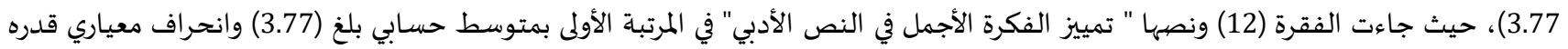
(1.06) وبنسبة مئوية (75.4\%)، وبدرجة مرتفعة. في حين جاءت الفقرة (14) ونصها " يحدد دلالات الفنون البلاغية ( بيان، ومعاني، وبديع)" بالمرتبة

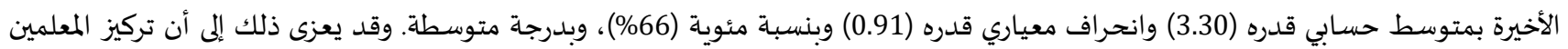
عادةً ما يكون عند تناولهم للنصوص الأدبية على الأفكار فقط دون التطرق إلى جماليات النص الأدبي المختلفة، كما أن معلمو اللغة العربية غالباً ما

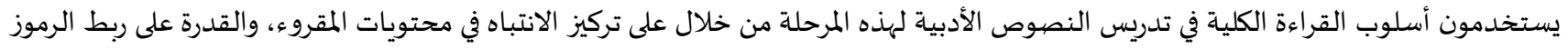

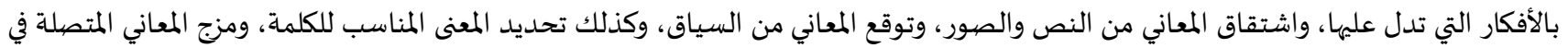

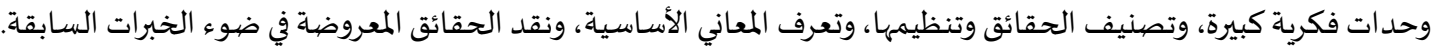

جدول (12): المتوسطات الحسابية والإنحر افات المعيارية لفقرات المجال النقدي مرتبة تنازلياً

\begin{tabular}{|c|c|c|c|c|c|c|}
\hline 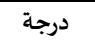 & 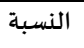 & 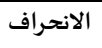 & المتوسط & 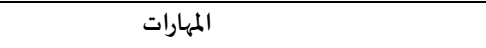 & 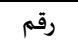 & 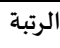 \\
\hline 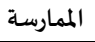 & المئوية & 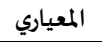 & 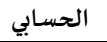 & & 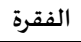 & \\
\hline متوسطة & \%73.4 & 0.91 & 3.67 & التمييز بين الأسباب والنتائج في النص الأدبي. & 19 & 1 \\
\hline 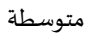 & $\% 71.8$ & 0.98 & 3.59 & التمييز بين الحقيقة والخيال في النص الأدبي. & 18 & 2 \\
\hline متوسطة & $\% 71.2$ & 0.96 & 3.56 & إصدار حكم على أسلوب الأديب في النص الأدبي. & 20 & 3 \\
\hline متوسطة & $\% 67.8$ & 1.14 & 3.39 & تحديد مواطن التأثر بالنص الأدبي. & 17 & 4 \\
\hline متوسطة & $\% 66.6$ & 0.97 & 3.33 & التمييز بين الدلالة الحقيقية والمجازية في النص الأدبي. & 21 & 5 \\
\hline متوسطة & $\% 70.2$ & 0.54 & 3.51 & الدرجة الكلية & & \\
\hline
\end{tabular}

يبين الجدول (12) أن تقديرات أفراد عينة الدراسة لدرجة ممارستهم للمجال النقدي كانت متوسطة بمتوسط حسابي بلغ (3.51)، وانحراف معياري قدره (0.54)، وبنسبة مئوية (70.2\%)، والمتوسطات الحسابية لتقديرات أفراد عينة الدراسة لفقرات المرات المجال النقدي تراوحت ما بين (3.33-

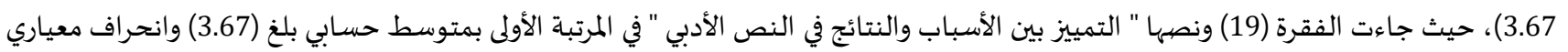
قدره (0.91) وبنسبة مئوية (73.4\%)، وبدرجة متوسطة. وقد يعزى ذلك إلى أن هذه المهارة من المهارات التي تتكرر باستمرار عند تدريس النصوص

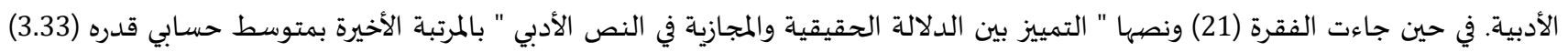

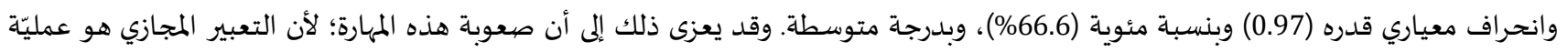
استخدام كلمة أو جملة معيّنة في سياق غير سياقها الاعتيادي. ويستخدم عادة في اللغة لإضـفاء نوع من الجمالية على النص، كما أنّ أغلبيتها تحدث أنماث

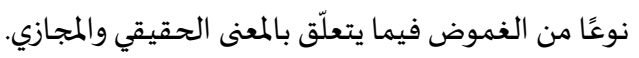

3.3. النتائج المتعلقة بالسؤال الثالث ومناقشتها: هل توجد علاقة ارتباطية بين درجة امتلاك معلمي اللغة العربية في المرحلة الأسساسية العليا في مديرية تربية البادية الشمالية الغربية لمهارات التذوق الأدبي وممارستهم لهاب التها؟ ولإجابة عن هذا السؤال تم حساب معامل ارتباط بيرسون بين درجة امتلاك معلمي اللغة العربية في المرحلة الأساسية العليا لمهارات التذوق الأدبي وممارستهم لها، والجدول (13) يوضح ذلك. 
جدول (13): معامل ارتباط بيرسون بين درجة امتلاك معلمي اللغة العربية لمهارات التذوق الأدبي وممارستهم لها

\begin{tabular}{|c|c|c|c|c|c|c|}
\hline ممارسة المهارات & النقدي & التذوقي & الوجداني & اللغوي & & المجال \\
\hline$* * 0.77$ & **0.71 & $* * 0.67$ & **0.73 & $* * 0.73$ & معامل الارتباط & اللغوي \\
\hline 0.00 & 0.00 & 0.00 & 0.00 & 0.00 & مستوى الدلالة & \\
\hline$* * 0.86$ & $* * 0.72$ & $* * 0.79$ & $* * 0.80$ & $* * 0.85$ & معامل الارتباط & الوجداني \\
\hline 0.00 & 0.00 & 0.00 & 0.00 & 0.00 & مستوى الدلالة & \\
\hline$* * 0.81$ & $* * 0.68$ & $* * 0.73$ & $* * 0.77$ & $* * 0.77$ & معامل الارتباط & التذوقي \\
\hline 0.00 & 0.00 & 0.00 & 0.00 & 0.00 & مستوى الدلالة & \\
\hline$* * 0.77$ & $* * 0.65$ & $* * 0.64$ & $* * 0.66$ & $* * 0.85$ & معامل الارتباط & النقدي \\
\hline 0.00 & 0.00 & 0.00 & 0.00 & 0.00 & مستوى الدلالة & \\
\hline$* * 0.84$ & $* * 0.71$ & $* * 0.76$ & $* * 0.76$ & $* * 0.85$ & معامل الارتباط & امتلاك المهارات \\
\hline 0.00 & 0.00 & 0.00 & 0.00 & 0.00 & مستوى الدلالة & \\
\hline
\end{tabular}

(* Correlation is significant at the 0.01 level (2-tailed).) ذات دلالة احصائية عند مستوى الدلالة (0.01) *

يتبين من الجدول (13) وجود علاقة ارتباطيه إيجابية (طردية) عند مستوى دلالة (a.05 م) بين درجة امتلاك معلمي اللغة العربية في المرحلة

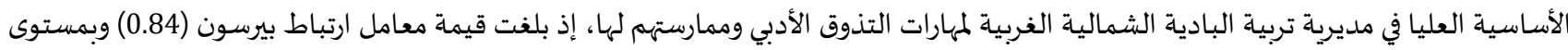
دلالة (0.000). كما يظهر وجود علاقة ارتباطيه إيجابية (طردية) عند مستوى دلالة (2 0.05) بين مجالات الامتلاك ومجالات الممارسة. ويفسر

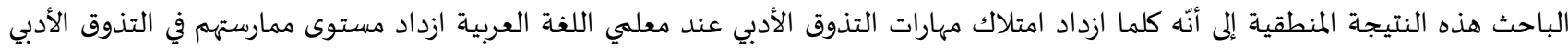

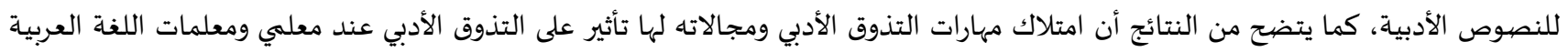
للمرحلة الأساسية العليا، وتدل هذه النتيجة على أنَّ امتلاك المهارات يسهم في التنبؤ بمستوى التذوق الأدبي عند المعلمين، من خلال قدرة المعلم على الماتى

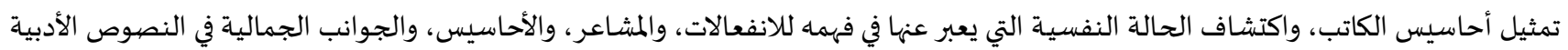
من أجل إتاحة الفرصة لطلابه للإلمام بجو العمل الأدبي، وتشجيعهم على محاكاة الإعمال الأدبية، ومحاولة التأليف على منوالها.

4.3. النتائج المتعلقة بالسؤال الر ابع ومناقشتها: هل توجد فروق ذات دلالة إحصبائية عند (0.05 0.0 ) في درجة امتلاك معلمي اللغة العربية في

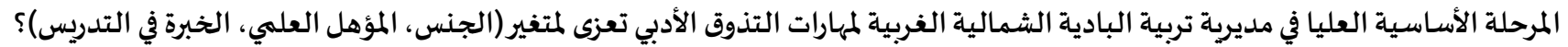

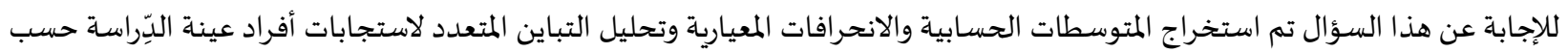
متغيرات الجنس، والمؤهل العلمي، والخبرة في التدريس، والجداول ذوات المدوات الأرقام (14، 15) تبين ذلك.

جدول (14): المتوسطات الحسابية والانحر افات المعيارية لدرجة امتلاك معلمي اللغة العربية لمهارات التذوق الأدبي تبعاً لمتغيرات الجنس والمؤهل العلمي وسنوات الخبرة

\begin{tabular}{|c|c|c|c|c|c|c|c|}
\hline الكلي & النقدي & التذوقي & الوجداني & اللغوي & المتوسط والانحراف & الفئات & المتغير \\
\hline 3.63 & 3.52 & 3.67 & 3.68 & 3.66 & المتوسط الحسابي & \multirow{2}{*}{ ذكر } & \multirow{4}{*}{ الجنس } \\
\hline 0.77 & 0.89 & 0.83 & 0.82 & 0.76 & الانحراف المعياري & & \\
\hline 3.57 & 3.48 & 3.68 & 3.61 & 3.53 & المتوسط الحسابي & \multirow[b]{2}{*}{ أنثى } & \\
\hline 0.76 & 0.84 & 0.85 & 0.83 & 0.75 & الانحراف المعياري & & \\
\hline 3.51 & 3.41 & 3.53 & 3.59 & 3.49 & المتوسط الحسابي & \multirow{3}{*}{ بكالوريوس } & \multirow{4}{*}{ المؤهل العلمي } \\
\hline 0.71 & 0.82 & 0.75 & 0.80 & 0.71 & الانحراف المعياري & & \\
\hline 3.73 & 3.62 & 3.87 & 3.71 & 3.71 & المتوسط الحسابي & & \\
\hline 0.82 & 0.90 & 0.92 & 0.85 & 0.81 & الانحراف المعياري & دراسات عليا & \\
\hline 3.44 & 3.36 & 3.53 & 3.47 & 3.41 & المتوسط الحسابي & \multirow{2}{*}{ أقل من 5 سنوات } & \multirow{4}{*}{ سنوات الخبرة } \\
\hline 0.75 & 0.82 & 0.78 & 0.88 & 0.76 & الانحراف المعياري & & \\
\hline 3.74 & 3.62 & 3.81 & 3.79 & 3.75 & المتوسط الحسابي & \multirow{2}{*}{5 سنوات فأكثر } & \\
\hline 0.76 & 0.88 & 0.88 & 0.74 & 0.72 & الانحراف المعياري & & \\
\hline
\end{tabular}

يبين الجدول (14) وجود فروق ظاهرية بين المتوسطات الحسابية لدرجة امتلاك معلمي اللغة العربية لمهارات التذوق الأدبي تبعاً لمتغيرات الجنس، والمؤهل العلمي، وسنوات الخبرة، ولتحديد فيما كانت الفروق بين المتوسطات ذات دلالة إحصائية عند مستوى دلالة (0.05 ب م)، تم

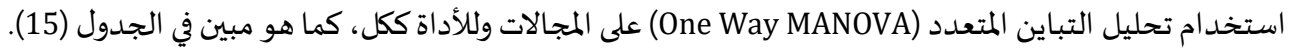




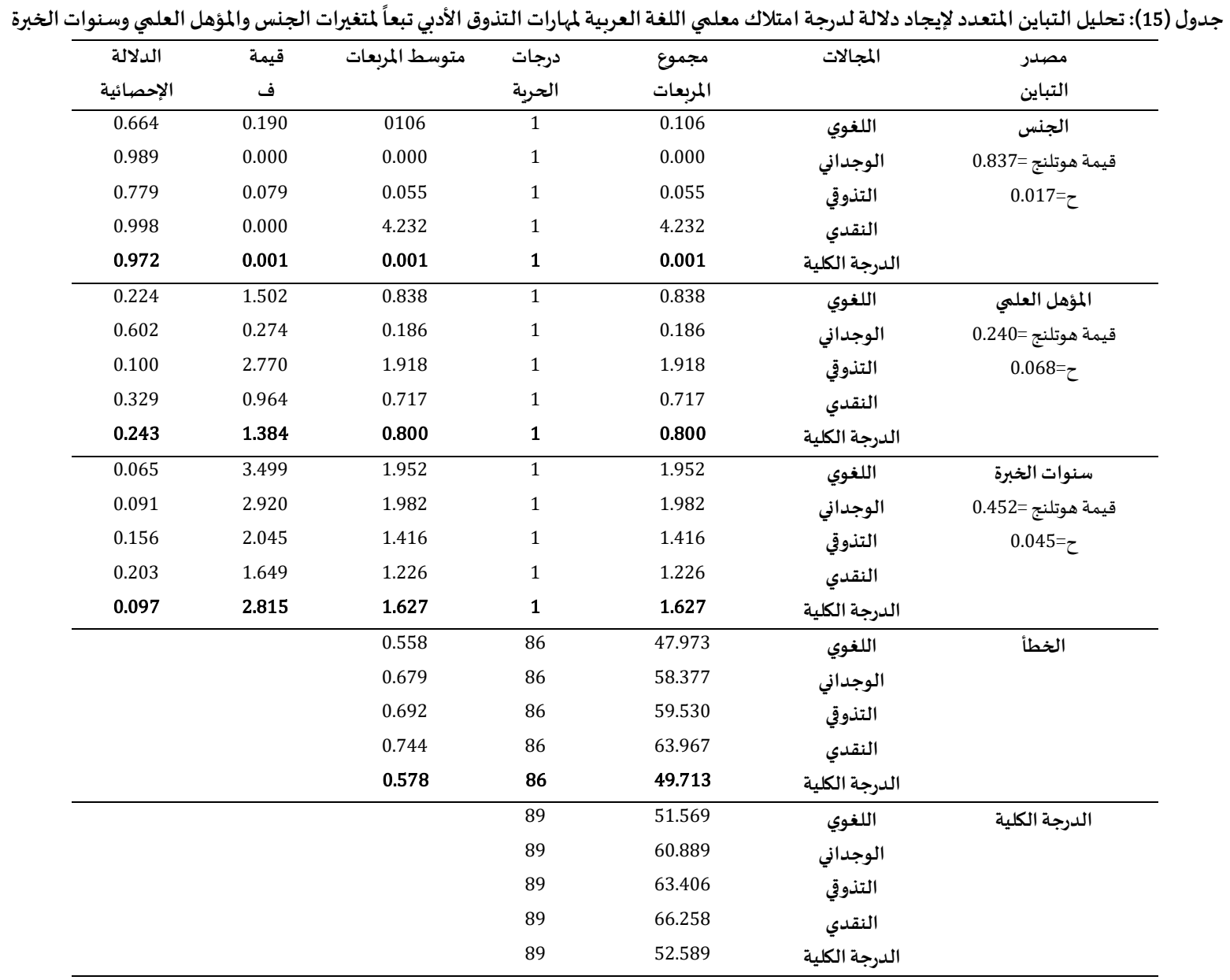

* ذات دلالة إحصائية (0.05)

يبين الجدول (15) عدم وجود فروق ذات دلالة إحصائية عند مستوى دلالة (0.05 م) لدرجة امتلاك معلمي اللغة العببية في المرحلة الأساسية

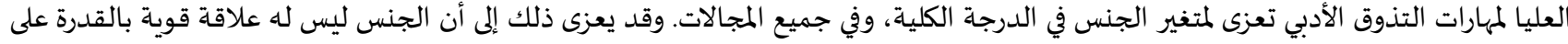

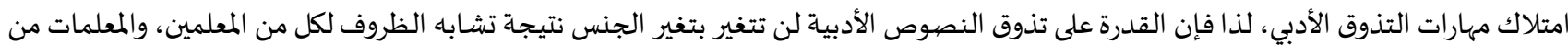

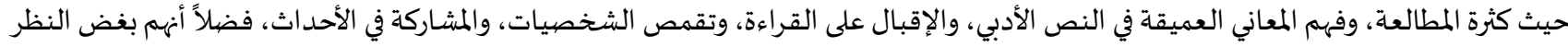

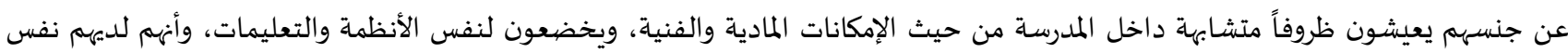

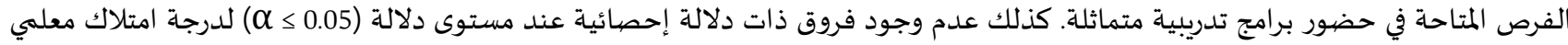

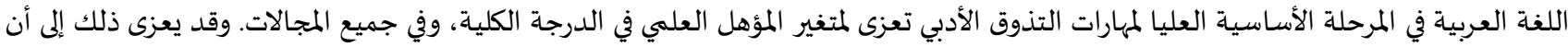

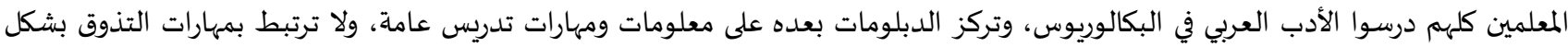

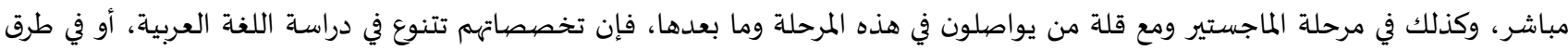

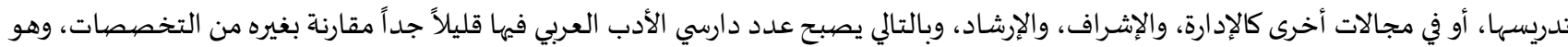

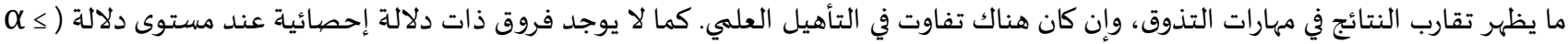

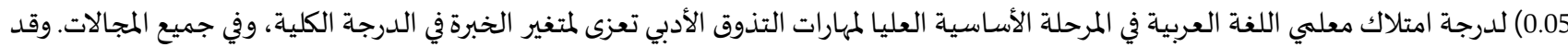

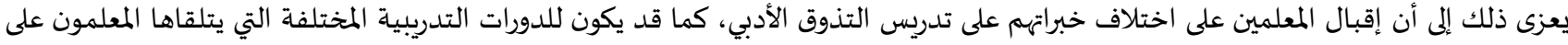

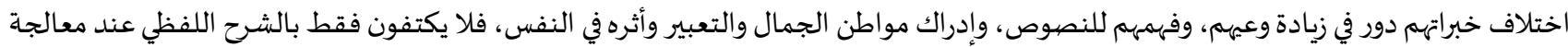

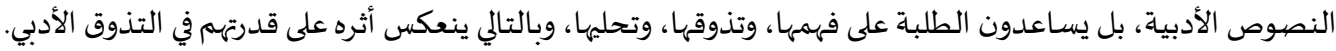

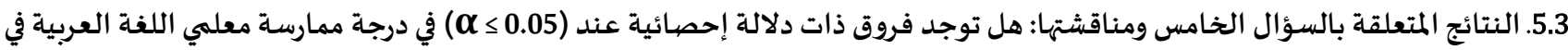

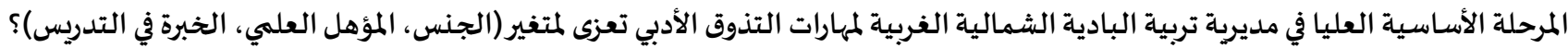

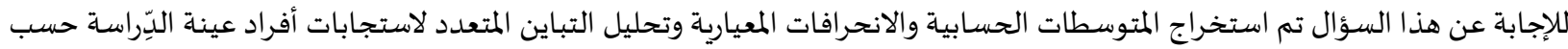

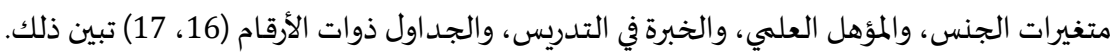


جدول (16): المتوسطات الحسابية والانحر افات المعيارية لدرجة ممارسة معلمي اللغة العربية لمهارات التذوق الأدبي تبعاً لمتغيرات الجنس والمؤهل العلمي وسنوات الخبرة

\begin{tabular}{|c|c|c|c|c|c|c|c|}
\hline الكلي ل & النقدي & التذوقي & الوجداني & اللغوي & & الفئات & المتغير \\
\hline 3.59 & 3.50 & 3.66 & 3.59 & 3.62 & المتوسط الحسابي & ذكر & الجنس الجس \\
\hline 0.46 & 0.63 & 0.64 & 0.75 & 0.60 & الانحراف المعياري & & \\
\hline 3.56 & 3.52 & 3.48 & 3.62 & 3.62 & المتوسط الحسابي & أنثى & \\
\hline 0.45 & 0.47 & 0.82 & 0.78 & 0.44 & الانحراف المعياري & & \\
\hline 3.58 & 3.62 & 3.57 & 3.54 & 3.60 & المتوسط الحسابي & بكالوريوس & المؤهل العلمي \\
\hline 0.43 & 0.52 & 0.67 & 0.71 & 0.56 & الانحراف المعياري & & \\
\hline 3.56 & 3.35 & 3.55 & 3.70 & 3.65 & المتوسط الحسابي & دراسات عليا & \\
\hline 0.49 & 0.53 & 0.85 & 0.84 & 0.45 & الانحراف المعياري & & \\
\hline 3.57 & 3.53 & 3.47 & 3.60 & 3.66 & المتوسط الحسـابي & أقل من 5 سنوات & سنوات الخبرة \\
\hline 0.39 & 0.48 & 0.78 & 0.73 & 0.44 & الانحراف المعياري & & \\
\hline 3.58 & 3.49 & 3.6 & 3.62 & 3.59 & المتوسط الحسابي & 5 سنوات فأكثر & \\
\hline 0.51 & 0.59 & 0.72 & 0.80 & 0.58 & الانحراف المعياري & & \\
\hline
\end{tabular}

يبين الجدول (16) وجود فروق ظاهرية بين المتوسطات الحسابية لدرجة ممارسة معلمي اللغة العربية لمهارات التذوق الأدبي تبعاً لمتغيرات

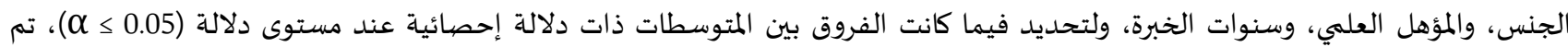

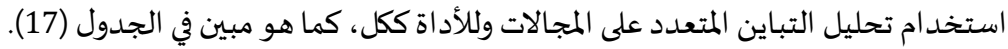

\begin{tabular}{|c|c|c|c|c|c|c|}
\hline الدلالة & قيمة & متوسط & درجات & مجموع المربعات & المجالات & مصدر \\
\hline الإحصائية & ف & المربعات & الحرية & & & التباين \\
\hline 0.785 & 0.075 & 0.021 & 1 & 0.021 & اللغوي & الجنس \\
\hline 0.952 & 0.004 & 0.002 & 1 & 0.002 & الوجداني & قيمة هوتلنج =0.867 \\
\hline 0.405 & 0.700 & 0.403 & 1 & 0.403 & التذوقي & $0.015=\tau$ \\
\hline 0.635 & 0.227 & 0.065 & 1 & 0.065 & النقدي & \\
\hline 0.799 & 0.065 & 0.014 & 1 & 0.014 & الدرجة الكلية & \\
\hline 0.552 & 0.357 & 0.099 & 1 & 0.099 & اللغوي & المؤهل العلمي \\
\hline 0.348 & 0.889 & 0.537 & 1 & 0.537 & الوجداني & قيمة هوتلنج =0.096 \\
\hline 0.965 & 0.002 & 0.001 & 1 & 0.001 & التذوقي & $0.098=\tau$ \\
\hline 0.071 & 5.887 & 1.695 & 1 & 1.695 & النقدي & \\
\hline 0.877 & 0.024 & 0.005 & 1 & 0.005 & الدرجة الكلية & \\
\hline 0.443 & 0.595 & 0.164 & 1 & 0.164 & اللغوي & سنوات الخبرة \\
\hline 1.000 & 0.000 & 6.588 & 1 & 6.588 & الوجداني & قيمة هوتلنج =0.658 \\
\hline 0.425 & 0.643 & 0.370 & 1 & 0.370 & التذوقي & $0.029=\tau$ \\
\hline 0.984 & 0.000 & 0.000 & 1 & 0.000 & النقدي & \\
\hline \multirow[t]{11}{*}{0.918} & 0.011 & 0.002 & 1 & 0.002 & الدرجة الكلية & \\
\hline & & 0.276 & 86 & 23.740 & اللغوي & \\
\hline & & 0.604 & 86 & 51.945 & الوجداني & الخطأ \\
\hline & & 0.576 & 86 & 49.563 & التذوقي & \\
\hline & & 0.288 & 86 & 24.754 & النقدي & \\
\hline & & 0.217 & 86 & 18.682 & الدرجة الكلية & \\
\hline & & & 89 & 23.972 & اللغوي & الدرجة الكلية \\
\hline & & & 89 & 52.514 & الوجداني & \\
\hline & & & 89 & 50.656 & التذوقي & \\
\hline & & & 89 & 26.496 & النقدي & \\
\hline & & & 89 & 18.711 & الدرجة الكلية & \\
\hline
\end{tabular}

ذات دلالة إحصائية (

يبين الجدول (17) عدم وجود فروق ذات دلالة إحصائية عند مستوى دلالة (20.05 م) لدرجة ممارسة معلمي اللغة العربية في المرحلة

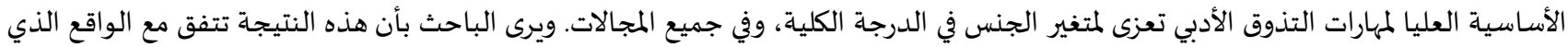

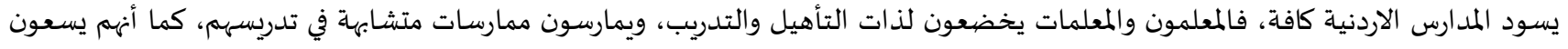


لتطبيق ذات التعليمات الصهادرة عن وزارة التربية، كما أنهم يعملون بتوجيهات متشابهة من موجهيهم التربويين بما يتعلق بممارساتهم التدريسياة، وهم

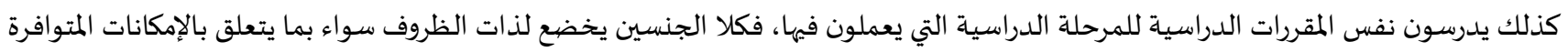

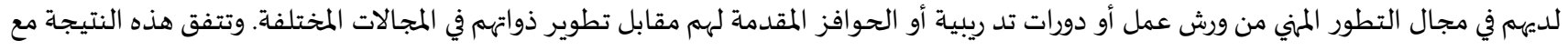

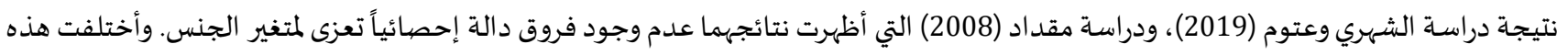
النتيجة مع نتيجة دراسـة حسن (2015) التي توصلت أنَّ هناك فروقاً ذات دلالة إحصائية تبعاً لمتغير الجنس لصدالح الإناث كذلك عدم وجود فروق ذات دلالة إحصائية عند مستوى دلالة (2 0.05) لدرجة ممارسة معلمي اللغة العربية في المرحلة الأساسية العليا

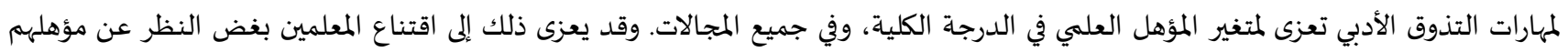

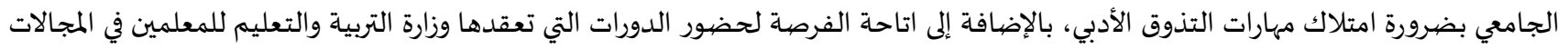

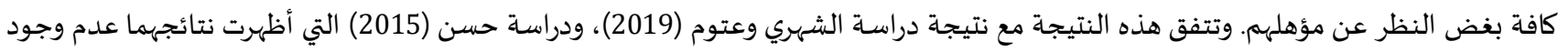

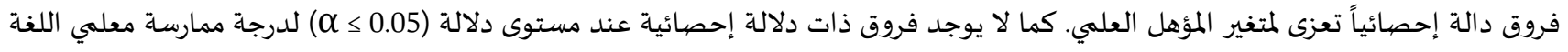

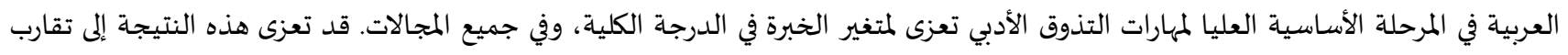

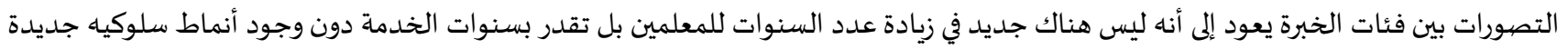

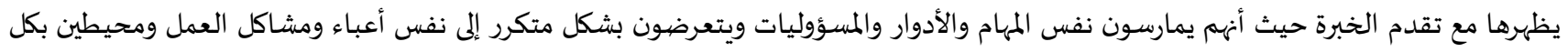

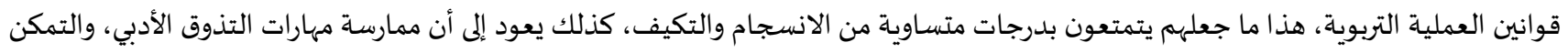

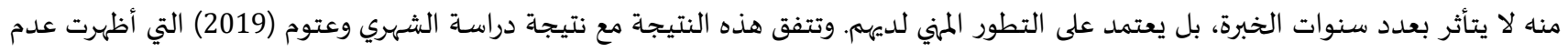

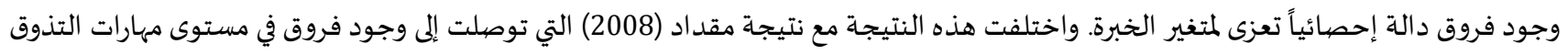
الأدبي تعزى إلى متغير سنوات الخبرة لصالح المعلمين من فئة 5 سنوات فأكثر.

6.3 التوصيات والمقترحات:

بناءً على نتائج الدِّراسـة يوصي البـاته

تدريب المعلمين على أهم استراتيجيات، وطرق تنمية مهارات التذوق الأدبي، من خلال عقد الدورات، وورش العمل التدريبية أثناء الخدمة. ضرورة اهتمام الجامعات بتزويد الطلبة المعلمين في أقسام اللغة العربية بالمهارات اللازمة التي تمكنهم من تدَّريس التذوق الأدبي في المدارس التي التي

سوف يعملون بها لاحقاً.

حث المعلمين على المطالعة الأدبية، والاطلاع على المجلات الأدبية والكتب النقدية والبلاغية ومتابعة الحركة الأدبية بكافة فنونها، وما يدور حولها

من نقد أدبي.

ضرورة التركيز في تدريس النصوص الأدبية على النواحي الوجدانية وتذوق تلك النصوص وخاصة التكرار في النص الأدبي. ضرورة تنمية مهارات التذوق الأدبي لدى معلمي اللغة العببية؛ وخاصة المهارات النقدية التي تتعلق بالتمييز بين الدلالة الحقيقية والمجازية والأسباب والنتائج في النص الأدبي.

إجراء دراسات مماثلة على عينات مختلفة، ومراحل تعليمية أخرى، كالمرحلة الثانوية، والابتدائية. إجراء دراسة فاعلية برنامج لتنمية كفايات معلمي اللغة العربية في تحليل النص الأدبي وأثره في إنماء مهارات التذوق الأدبي لدى طلبتهم.

أولاً: المراجع العربية:

1. البكر، فهد (2013). أثر استخدام إستراتيجية التدريس التبادلي في تدريس النصوص الأدبية على تنمية مهارات التذوق الأدبي لدى تلميذات

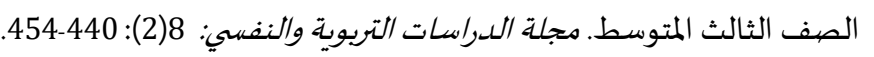
2. آل تميم، عبد الله محمد (2015). تقويم مهارات التذوق الأدبي لدى طلاب المرحلة المتوسطة بمكة المكرمة. رسالة التوبية وعلم النفس، 3(48):

3. حبوش، رندة ومقابلة، نصر محمد (2017). أثر أنموذج الاستماع التكاملي في تحسين التذوق الأدبي لدى طالبات الصف العاشر الأساسي في

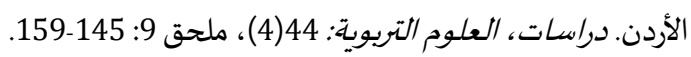
4. حسن، فراس عبد الله (2015). ملىى ممارسة مدرسي اللغة العببية لمهارات التذوق الأدبي في موضيوعات الأدب والنصيوص للدى طلبة الصفف الرابع الأدبي في العرقاق. رسالة ماجستير غير منشورة، جامعة آل البيت، المفرق، الاردن. 
5. الخيري، بدر علي (2014). تقويه نشاطات التعلم في مقرر لغتي الخالدة في ضيوء مهارات التنوق الأدبي اللازهة لتلميذ الصف الاول المتوسط. رسالة ماجستير غير منشورة، جامعة أم القرى، السعودية.

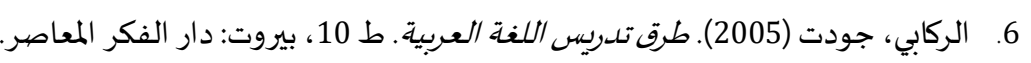

7. الزبيدي، نسرين أحمد (2011). أثر بزنامج تعليهي قائمر على المنتى التواصلي في تحسين مهارات الاستماع الناقد والتذوق الأدبي للدى طلبة الصفف

التاسع الأساسي. أطروحة دكتوراه غير منشورة، جامعة اليرموك، اربد، الأردن.

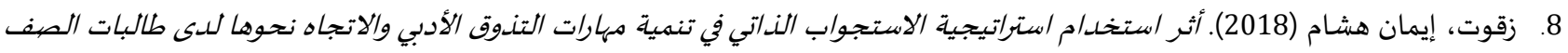

العاشر الأساسي. رسالة ماجستير غير منشورة، الجامعة الإسلامية، غزة، فلسطين.

9.9

10. الشديفات، أشجان (2013). بناء برنامج تعليمي قائم على مهارات التذوق الأدبي بالمستوى الإبداعي من خلال تدريس النصوص الأدبية لدى طلبة

قسم اللغة العربية في كلية الآداب في الجامعة الهاشمية. المجلة العببية للدراسات التربوية والاجتماعية: 3: 53-69.

11. الشهري، محمد وعتوم، عبد القادر (2019). مستوى الذكاء الانفعالي وعلاقته بمهارات التذوق الأدبي لدى معلمي ومعلمات اللغة العربية للفيه للمرحلة

الثانوية في منطقة نجران. المجلة التويوية الدولية المتخصصصة: 8(1): 48-60.

12. عبد الباري, ماهر شعبان (2014). التندوق الأدبي: النظرية والتطبيق. الدمام: مكتبة المتنبي للنشر والتوزيع.

13. عبد الباري، ماهر شعبان (2016). التذوق الأدبي: طبيعته، نظرياته، مقوماته، معاييره، قياسه. عمان: دار الفكر للنشر والتوزيع.

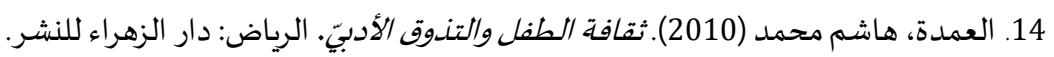

15. العيد، الخامسة صالح (2010). فاعلية تلديس النصيوص الشعبية بأسلوب التمثيل الدرامي في الاستيعاب القرائي والتذوق الأدبيّ لدى تلميذات

الصفف الثالث المتوسط في ملدينة الرياض. أطروحة دكتوراه غير منشورة، جامعة عمان العربية، الأردن.

16. محمد، جمال محمود (2013). فاعلية برنامج لتنمية كفايات معلمي اللغة العببية في تحليل النص الأدبي وأثثره في إنماء مهارات التذوق الأدبي لدى الدى طلاب الممحلة الثانوية بلدولة الإمارات العببية المتحدة. أطروحة دكتوراه غير منشورة، جامعة القاهرة، معهد الدراسات والبحوث التربوية، القاهرة، مصر.

17. مدكور، علي (2006).تدريس فنون اللغة العربية. ط3، القاهرة: دار الفكر العربي. 18. مقداد، عصام (2008). مستوى مهارات التذوق الأدبي للدى معلمي اللغة العربية بالمرحلة الأساسية العليا وعلاقته بمستوى الثقافة الإسلامية للديهم. رسالة ماجستير غير منشورة، الجامعة الإسلامية، غزة، فلسطين. 19. مناع، محمد وطعيمة،، رشدي (2000). تدريس العربية في التعليم العام: نظريات وتجارب. القاهرة: دار الفكر العربي. 20. الهزايمة، سـامي (2009). أثر طريقة تقديم النصوص في مهارات التذوق الأدبي وعلاقته بالجنس لدى طلبة الصف العاشر الأسـاسي في الأردن، مجلة جامعة أم القرى للعلوم التويوية والنفسية: 1(2): 321-352.

ثانياً: المراجع الأجنبية:

1. Emmert, P. (1994). A definition of listening. Listening Post, 51(6): 115- 190.

2. Flood, J., \& Lapp, D. (2002). Developing Literary Appreciation and Literacy Skills. Reading Teacher, 78 (1): $215-286$.

3. Rosario, M. (2001). Contesting: The Role of Aesthetic in Reading Difficult Literature, Dissertation Abstract international, (A62/03): 909. 
المجلة الدولية للدراسـات التربوية والنفسية

International Journal of Educational \& Psychological Studies (EPS)

Journal Homepage: https://www.refaad.com/views/EPSR/Home.aspx

www.refaad.com

ISSN: 2520-4149 (Online) 2520-4130 (Print)

\title{
The degree of the Arabic teachers possess in the upper basic stage in northwest Badia district of the skills of literary appreciation and practicing it
}

\author{
Adeeb Diab Hamadnah \\ Professor of Arabic language curricula and methods of teaching, College of Educational Sciences, \\ Al Albayt University, Jordan \\ adeebhamadnah@yahoo.com
}

Received : 26/6/2021 Revised : 8/7/2021 Accepted : 7/8/2021 DOI : https://doi.org/10.31559/EPS2021.10.3.4

Abstract: This study aimed at finding the degree of Arabic language teachers' possession in the upper basic stage in Northwest Badia district of the skills of literary appreciation and practicing it. The study sample consisted of (90) male and female teachers. It was conducted by using a questionnaire after assuring its validity and readability including (21) items distributed into four fields. The study results revealed that the degree of Arabic language teachers' possession in the upper basic stage in Northwest Badia district of the skills of literary appreciation and practicing it showed a medium degree at the tool as a whole. Where the arithmetic mean of the degree of possession was (3.6) and a percentage (72\%), the arithmetic mean of the degree of practice was (3.58) and a percentage (71.6\%). The results showed that there were no statistically significant differences between the averages of the estimates of the study sample in the degree of Arabic language teachers' possession in the upper basic stage in Northwest Badia district of the skills of literary appreciation due to variables of gender, educational qualification and experience in the tool as a whole. Results showed that also there were no statistically significant differences between the averages of the estimates of the study sample in the degree of Arabic language teachers' practice in the upper basic stage in Northwest Badia district of the skills of literary appreciation due to variables of gender, educational qualification and experience in the tool as a whole. There is also a positive correlation the value of the Pearson correlation which was (0.84) between the degree to which Arabic language teachers at the higher basic stage in Northwest Badia district possession of the skills of literary appreciation and their practice of it. The study recommends: Training teachers on the most important strategies and methods of developing literary appreciation skills, through holding courses and in-service training workshops.

Keywords: Degree of ownership; Degree of practicing; Literary appreciation skills; Arabic language teachers.

\section{References:}

1. 'bd Albary, Mahr Sh'ban (2014). Altdwq Aladby: Alnzryh Walttbyq. Aldmam: Mktbt Almtnby Llnshr Waltwzy'.

2. 'bd Albary, Mahr Sh'ban (2016). Altdwq Aladby: Tby'th, Nzryath, Mqwmath, M'ayyrh, Qyash. 'man: Dar Alfkr Llnshr Waltwzy'.

3. Al'mdh, Hashm Mhmd (2010). Thqafh Altfl Waltdwq Aladby. Alryad: Dar Alzhra' Llnshr.

4. Al'yd, Alkhamsh Salh (2010). Fa'lyt Tdrys Alnsws Alsh'ryh Baslwb Altmthyl Aldramy Fy Alasty'ab Alqra'y Waltdwq Aladby Lda Tlmydat Alsf Althalth Almtwst Fy Mdynt Alryad. Atrwht Dktwrah Ghyr Mnshwrh, Jam't 'man Al'rbyh, Alardn.

5. Albkr, Fhd (2013). Athr Astkhdam Estratyjyh Altdrys Altbadly Fy Tdrys Alnsws Aladbyh 'la Tnmyt Mharat Altdwq Aladby Lda Tlmydat Alsf Althalth Almtwst. Mjlt Aldrasat Altrbwyh Walnfsy: 8(2): 440-454.

6. Hbwsh, Rndh Wmqablh, Nsr Mhmd (2017). Athr Anmwdj Alastma' Altkamly Fy Thsyn Altdwq Aladby Lda Talbat Alsf Al'ashr Alasasy Fy Alardn. Drasat, Al'lwm Altrbwyh: 44(4), Mlhq 9: 145-159.

7. Hsn, Fras 'bd Allh (2015). Mda Mmarsh Mdrsy Allghh Al'rbyh Lmharat Altdwq Aladby Fy Mwdw'at Aladb Walnsws Lda Tlbh Alsf Alrab' Aladby Fy Al'raq. Rsalt Majstyr Ghyr Mnshwrh, Jam't Al Albyt, Almfrq, Alardn.

8. Alhzaymh, Samy (2009). Athr Tryqt Tqdym Alnsws Fy Mharat Altdwq Aladby W'laqth Baljns Lda Tlbh Alsf Al'ashr Alasasy Fy Alardn, Mjlt Jam't Am Alqra Ll'lwm Altrbwyh Walnfsyh: 1(2): 321-352. 
9. Alkhyry, Bdr 'ly (2014). Tqwym Nshatat Alt'lm Fy Mqrr Lghty Alkhaldh Fy Dw' Mharat Altdwq Aladby Allazmh Ltlmyd Alsf Alawl Almtwst. Rsalt Majstyr Ghyr Mnshwrh, Jam't Am Alqra, Als'wdyh.

10. Mdkwr, 'ly (2006). Tdrys Fnwn Allghh Al'rbyh. T3, Alqahrh: Dar Alfkr Al'rby.

11. Mhmd, Jmal Mhmwd (2013). Fa'lyt Brnamj Ltnmyh Kfayat M'lmy Allghh Al'rbyh Fy Thlyl Alns Aladby Wathrh Fy Enma' Mharat Altdwq Aladby Lda Tlab Almrhlh Althanwyh Bdwlt Alemarat Al'rbyh Almthdh. Atrwht Dktwrah Ghyr Mnshwrh, Jam't Alqahrh, M'hd Aldrasat Walbhwth Altrbwyh, Alqahrh, Msr.

12. Mna', Mhmd Wt'ymh, Rshdy (2000). Tdrys Al'rbyh Fy Alt'lym Al'am: Nzryat Wtjarb. Alqahrh: Dar Alfkr Al'rby.

13. Mqdad, 'sam (2008). Mstwa Mharat Altdwq Aladby Lda M'lmy Allghh Al'rbyh Balmrhlh Alasasyh Al'lya W'laqth Bmstwa Althqafh Aleslamyh Ldyhm. Rsalt Majstyr Ghyr Mnshwrh, Aljam'h Aleslamyh, Ghzh, Flstyn.

14. Alrkaby, Jwdt (2005). Trq Tdrys Allghh Al'rbyh. T 10, Byrwt: Dar Alfkr Alm'asr.

15. Alshdyfat, Ashjan (2013). Bna' Brnamj T'lymy Qa'm 'la Mharat Altdwq Aladby Balmstwa Alebda'y Mn Khlal Tdrys Alnsws Aladbyh Lda Tlbt Qsm Allghh Al'rbyh Fy Klyt Aladab Fy Aljam'h Alhashmyh. Almjlh Al'rbyh Lldrasat Altrbwyh Walajtma'yh: 3: 53-69.

16. Alshhry, Mhmd W'twm, 'Ebd Alqadr (2019). Mstwa Aldka' Alanf'aly W'laqth Bmharat Altdwq Aladby Lda M'Imy Wm'lmat Allghh Al'rbyh Llmrhlh Althanwyh Fy Mntqt Njran. Almjlh Altrbwyh Aldwlyh Almtkhssh: 8(1): 48-60.

17. Al Tmym, 'bd Allh Mhmd (2015). Tqwym Mharat Altdwq Aladby Lda Tlab Almrhlh Almtwsth Bmkh Almkrmh. Rsalt Altrbyh W'Im Alnfs, 3(48): 55-76.

18. Alzbydy, Nsryn Ahmd (2011). Athr Brnamj T'lymy Qa'm 'la Almnha Altwasly Fy Thsyn Mharat Alastma' Alnaqd Waltdwq Aladby Lda Tlbt Alsf Altas' Alasasy. Atrwht Dktwrah Ghyr Mnshwrh, Jam't Alyrmwk, Arbd, Alardn.

19. Zqwt, Eyman Hsham (2018). Athr Astkhdam Astratyjyh Alastjwab Aldaty Fy Tnmyt Mharat Altdwq Aladby Walatjah Nhwha Lda Talbat Alsf Al'ashr Alasasy. Rsalt Majstyr Ghyr Mnshwrh, Aljam'h Aleslamyh, Ghzh, Flstyn.

20. Zqwt, Mhmd Shhadh. (2013). Almrshd Fy Tdrys Allghh Al'rbyh. Ghzh: Mnshwrat Aljam'h Aleslamyh. 